\title{
A comparative geological, tectonic and geomorphological assessment of the Charlotte, Regent and Madina landslides, Western area, Sierra Leone
}

\author{
Yusuf Alhaji Lahai ${ }^{1 *}$, Kelvin F. E. Anderson ${ }^{1,2}$, Yaguba Jalloh'1 , Ibrahim Rogers ${ }^{3}$ and Mohamed Kamara²
}

\begin{abstract}
This work focused on three landslide events that have attracted significant public concern due to the associated calamities they recorded in 1945, 2017 and 2019, i.e. the Charlotte, Regent and Madina landslides, respectively. Their geology, tectonics (structural discontinuities) and geomorphology, i.e. their GTG characteristics were studied to establish links between them and the landslide events.

Field surveys were conducted, particularly on the Charlotte landslide, where the identification of geological structures was impeded to an extent by its obliteration by vegetation and sediment accumulations on relatively planar sections of the landslide area. Remote sensing and GIS techniques (earth imagery and drone images) enhanced the mapping and determination of landslides' geometric and geomorphic parameters. Laboratory analyses of rock and soil samples provided the landslides' petrological characterisation and were used to determine the particle-size distribution in the slide-prone soil.

The study indicated a change in the gabbroic rock composition, variable geomorphological characteristics, and nature/ pattern and density of the discontinuities. These factors, to a large extent, determined the nature and magnitude of the rainfall-triggered landslides. Charlotte lithology slightly differed from the other two landslides and recorded higher Silica (Si) and Aluminum (Al) and lower iron (Fe) from X-Ray Fluorescence (XRF) than rocks of Regent and Madina landslides. The study also revealed only a tenuous correlation between rock composition and weathering depth. The slope angles at the landslides' prominent scarps (depletion zone) are steep ( $>45$ degrees) with altitudes of approximately $270 \mathrm{~m}, 200 \mathrm{~m}$ and $470 \mathrm{~m}$ above sea level for Charlotte, Regent and Madina, respectively. Unlike the Charlotte landslide, both Regent and Madina landslides are active, but geometrically, their area, length and run-out distances have relatively high variance with a coefficient of variance equals to 1. Information derived from this work can help understand the spatial variation in landslide characteristics and develop a susceptibility map.
\end{abstract}

Keywords: Geology, Geomorphological characteristics, Mapping, Petrological characterisation, Tectonics

\footnotetext{
* Correspondence: lahaialhajiyusuf@yahoo.com

'Department of Geology, Fourah Bay College, University of Sierra Leone,

Freetown, Sierra Leone

Full list of author information is available at the end of the article
}

\section{Springer Open}

(c) The Author(s). 2021 Open Access This article is licensed under a Creative Commons Attribution 4.0 International License, which permits use, sharing, adaptation, distribution and reproduction in any medium or format, as long as you give appropriate credit to the original author(s) and the source, provide a link to the Creative Commons licence, and indicate if changes were made. The images or other third party material in this article are included in the article's Creative Commons licence, unless indicated otherwise in a credit line to the material. If material is not included in the article's Creative Commons licence and your intended use is not permitted by statutory regulation or exceeds the permitted use, you will need to obtain permission directly from the copyright holder. To view a copy of this licence, visit http://creativecommons.org/licenses/by/4.0/. 


\section{Introduction}

Mountainous areas worldwide have the propensity to be affected by landslides, and these events have continuously caused fatalities and damages to property (Dai et al. 2002; Corominas et al., 2013). Records have shown the level of impact they have inflicted on several countries. In Italy, at least 263 lives were lost from mass movement in nine years (1990-1999) (Guzzetti, 2000). Two hundred landslides claimed more than 500 lives in the Himalayas (Kumar et al., 2014). Two villages were consumed by landslide debris, and 99 people were killed along its run-out path in China (Xing et al. 2015). More than 8800 fatalities and enormous economic losses were caused by a 7.8 magnitude earthquake in 2015 in Gorkha Nepal (Xu et al., 2017). Therefore, knowledge of surface characteristics, underlying geology and tectonic setting of hilly and mountainous regions is crucial for alleviating this global threat to humans, infrastructure and the environment.

The hilly and mountainous central part of the Freetown Layered Complex has documented more landslide events and caused colossal losses (UNDP and EPA, 2017; Bruce 2019) than any other place within the Layered Complex (FCC 2014; INTEGEMS 2017; Arup, BGS, JBA, and INTEGEMS, 2018). One such incident was the Regent landslide which affected the Sugarloaf Mountain and claimed more lives (i.e.1, 100 people) than anywhere globally in 2017 (Redshaw et al., 2019). These landslides were produced under certain geologic, geomorphologic and hydrologic conditions, which may reoccur. Studying these characteristics to understand their relationships with landslide incidents, will help the authorities make informed decisions to mitigate such occurrences.

Studies by few researchers such as Delmonaco et al. (2005); Chigira (2006); Nakano et al. (2015); Vipin et al. (2018); Borrelli et al. (2018); Lupiano et al. (2018) and Segoni et al. (2019), have shown that landslide events are linked to the geology (rock types) and geomorphology. Nugraha et al. (2015) mentioned that geomorphometric characteristics have the most significant relationship with landslide distribution. Research has also revealed that landslide occurrence can be closely connected to anthropogenic factors (e.g. deforestation, slope undercutting and construction) (Skilodimou et al., 2018; Cui et al. 2019; Jin et al. 2020), and geological structures (Cerri et al. 2017).

Despite the socio-economic and geomorphologic impacts of landslides (Ngeku and Mathu, 1999; Ngeku et al. 2004; Jacobs et al. 2016), which are expected to increase with global climate change (Nugraha et al., 2015; Broeckx et al. 2018), studies are still rare in the Africa continent (Maes et al., 2017, Broeckx et al. 2018), considering the available scientific literature (e.g. Knapen et al. 2006; Van Den Eeckhaut et al., 2009; Kimaro et al.
2010; Moeyersons et al., 2010; Nibigira et al. 2013; Msilimba 2010; Msilimba and Holmes 2010; Bouhadad et al. 2010; Ndyanabo et al. 2011; Che et al. 2011; Hardwick 2012; Broothaerts et al. 2012; Asma 2013; Maki Mateso and Dewitte 2014; Afungang, 2015; Bourenane et al. 2015; Royal Museum for Central Africa, 2016; Maertens 2016; and Jacobs et al. 2016). Also, based on the data presented by Broeckx et al. (2018) (i.e. an overview of all mapped landslides by country), only 13 (25\%) of African countries are represented in the global landslide research. The majority of them are recorded in the EastAfrican Rift region (Ethiopia, Uganda, DR Congo, Tanzania, Malawi and South-Africa) and a few in the northernmost regions of Maghreb country (e.g. Algeria) and West Africa (Cameroon and Nigeria). These landslides are caused by two or more causal factors with some characteristics common to most landslide sensitive areas (Broothaerts et al. 2012). In West Africa, rainfall primarily triggers landslide occurrences (Igwe 2015), and these act more effectively by preconditioning factors (rock type, deeply weathered soil, discontinuities and steep slopes). These factors are crucial in explaining their imprints on landslides and their observed spatial pattern, and as such, their assessment is necessary. This study attempts to fill the gap in landslide research in this part of Africa, which centres on three significant slides' comparative geology, tectonics and geomorphology (GTG) characteristics.

In Sierra Leone, landslide knowledge is constrained by minimal and restricted scientific landslide studies (e.g. Thomas, 1983, 1994 \& Thomas, 1998; Cui et al., 2019, Redshaw et al., 2019; Lahai and Lahai Jr, 2019; Jin et al. 2020), amidst a surge of landslides in its capital city. This is supported by the exclusion of localised landslide crises in the Global Landslide inventories (e.g. International Emergency Database (EMDAT), the Global Disaster Identifier (GLIDE)) (e.g. Monsieurs et al. 2018 and Broeckx et al. 2018), despite its severe impacts. This indicates a shortage of landslide knowledge in this part of the world. Excluding Thomas (1983, 1994 \& 1998), records show that the few available studies had focused on the Regent landslide with much emphasis on the link between the event and urbanisation than other factors. The influences of geology, geomorphology and geological structures on landslide occurrences have neither been studied nor well defined as landslide characteristic data remain poor or nonexistent. Also, no attempt has been made to contrast the country's significant landslides regarding their GTG characteristics to understand their spatial features in the study area's spatial characteristics. This work, therefore, provides the impetus for fulfilling this gap, through the systematic characterisation of the slides. 
In this work, three spatially distributed landslides at Charlotte, Regent and Madina in the western area rural district were considered. They occurred in August 1945, 2017 and 2019, respectively, with no record of seismic activities. The main triggering factor was rainfall, which was established by Froude and Petley (2018) in their global database of fatal non-seismic landslides. Additionally, the country's seismic hazard level is very low, and earthquake-triggered landslides would be extremely unlikely within a 50-year return period (Arup, BGS, JBA, and INTEGEMS, 2018). The landslides show marked variation in form, scale and mode of occurrence, which appeared to be significantly controlled by the geological setting (e.g. Igwe 2015) and topography (geomorphic elements). As such, site-specific geological traces and geomorphologic reconstructions of the three slides based on field surveys were undertaken. The data on GTG characteristics, triggering and causative factors; soil type; failure types and run-out distance obtained from the three landslide sites were compared to facilitate a better understanding of the slides' nature. This knowledge could eventually be used to make a more accurate prediction of landslide events within the area.

This study significantly contributes to the various physical processes associated with regional hazard mapping and landslide inventory. The detailed, systematic and localised data generated from the research could be fundamental for policymakers and development practitioners. This can also be shared with the Office of the National Security (ONS) and other relevant institutions/ departments for consideration during the formulation of any disaster-related Policy.

\section{Study area}

\section{Introduction}

The study focuses on the South-western part of the country's capital city, Freetown, characterised by dissected and tropical landscapes (i.e. dissected peaks) with considerable geomorphological evidence of old translational slides (Thomas 1994). Thomas (1998) initially mapped these historic and ancient landslides, and the British Geological Survey (BGS) later modified his work. The three slides, which have been considered and assessed, occurred in the mountain villages within this study area. Specifically, they were inventoried and mapped at Charlotte $\left(8^{0} 42 \mathrm{~N}, 13^{0} 23^{\prime} \mathrm{W}\right)$, Regent $\left(8^{0} 39^{\prime}\right.$ $\left.\mathrm{N}, 13^{0} 21^{\prime} \mathrm{W}\right)$ and Madina $\left(8^{0} 42 \mathrm{~N}, 13^{0} 21 \mathrm{~W}\right)$ (Fig. 1), and they are represented in Fig. 1 covering an area of approximately $47 \mathrm{~km}^{2}$.

The study area belongs to the 4th geomorphological class of Sierra Leone, comprising hills of basic and ultrabasic rocks. The area consists of steep slopes ranging from $181 \mathrm{~m}$ to $901 \mathrm{~m}$ above mean sea level. One of the two hills with the highest peak, Sugar Loaf Hill, which recorded the most devastating landslide, falls within the study area. The southward extension of the Sugarloaf Hill and adjacent ones (in the east and western part of the hill) at Regent falls within protected forest highlands threatened by encroachment due to uncontrolled urban developments. This has made these hills subject to continuous slope failures/instability, which is further exacerbated by activities such as stone mining, sediment piling along Regent-Madina Babadorie valley during the Regent Landslide stabilization project by the United Nations Office for Project Services (UNOPS) and subsequent slope collapse caused by slope undercutting (denuded hills and more extensive valleys).

Climatologically, all the areas experience a tropical and humid climate mainly controlled by the tropical air mass affecting the entire sub-region (Taylor et al., 2014). The climate of the Freetown Complex has characteristically high rainfall of 3000-5000 mm/year (Bowles et al. 2017) with an average exceeding $3500 \mathrm{~mm}$ (Sankoh and Yan 2013). Rainfall data analysis obtained from the country's Meteorological Agency indicates a higher amount of precipitation from July to September, with the highest rain recorded in August. This month is regarded as the height of the rainy season with a mean of up to 1394 $\mathrm{mm}$ (Fig. 2). The rainfall condition that caused the Charlotte landslide was recorded beyond $1000 \mathrm{~mm}$ over 5 days and $400 \mathrm{~mm}$ in the $24 \mathrm{~h}$ preceding the failure (Redshaw et al. 2019). A total rain of $1040 \mathrm{~mm}$ of rain in 6 weeks (1 July - 14 August 2017) tripled the seasonal average for Freetown (Clarke 2017), which sufficiently saturated the soil to trigger the Regent twin disasters (Cui et al. 2019). The Madina event occurred following heavy rainfall on 2 August 2019, which recorded approximately $187 \mathrm{~mm}$ of rain. Figure 2 shows the monthly average rainfall for the years these landslides occurred.

In effect, the steep slopes and heavy rainfall, coupled with shallow soils and intense weathering in the Freetown Layered Complex make the study area susceptible to slope failures both at the bedrock-regolith interface and along planes of weakness (clay-filled joints).

\section{Regional geological context}

The study area lies in the Western Rural area and is part of the Freetown-Layered Complex (FLC) of Sierra Leone. It is a Mesozoic mafic intrusion (Goodenough et al. 2018) that is $65 \mathrm{~km}$ long, $14 \mathrm{~km}$ wide and $7 \mathrm{~km}$ thick in dimensions (Chalokwu 2001). It forms part of the West African Craton, bounded to the east and west by the Pan African-aged mobile belts (Ennih \& Li geois 2008; Schluter \& Trauth 2008). The study area is in the Archaean craton's central core but is now separated into the Liberian craton in Africa and the Guyana Shield of northern South America (Hattori et al. 1991). Chalokwu et al. (1999), noted that the complex intruded at mid- 


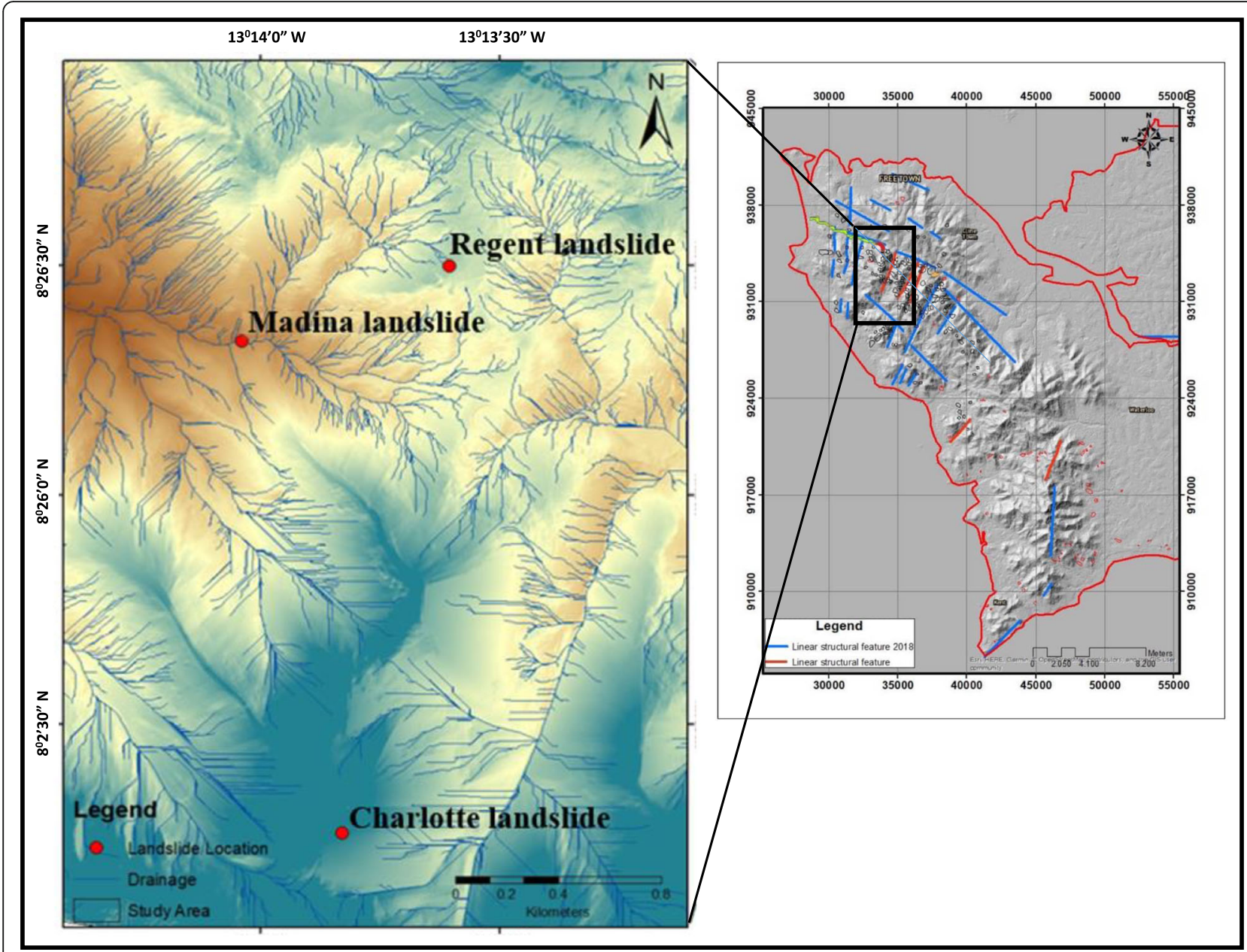

Fig. 1 Study area showing landslide locations projected from the regional lineament map of Freetown

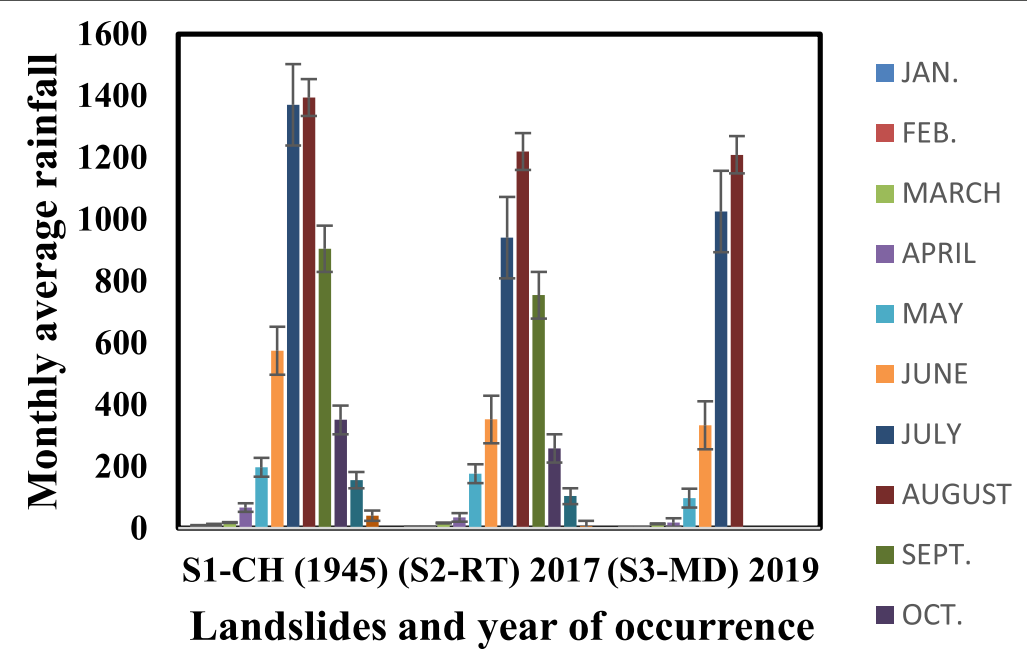

Fig. 2 Monthly average rainfall for the years the studied landslides occurred 
crustal depths within the metamorphic terranes of the Kasila Group, which is part of the Rokelide orogenic belt. In effect, this Rokelide Proterozoic mobile belt serves as the emplacement site for the FLC (Callegaro et al. 2017), in which linearity and trend coincide with an igneous origin closely related to Atlantic rifting and early movements along the Guineé Fracture zone (Venkatakrishnan and Culver, 1989).

In terms of tectonic fabric, four main lineament trends (NNW-SSE, N-S, NNE-SSW and ENE-SSE) have been identified in Sierra Leone (e.g. Venkatakrishnan \& Culver 1989). This was done by interpreting Landsat images and integrating the result with available geological and geophysical data from Sierra Leone's offshore and onshore regions. These lineaments are directly linked to the Archaean fabric in the Leo Uplift. Their patterns relate to intraplate and plate marginal reaction of preexisting structures during Mesozoic rifting events that resulted in strong tectonic controls on magmatism (Venkatakrishnan and Culver, 1989). Far inland intraplate deformation accompanied rifting events, evident by the four lineament trends, on which are focused Mesozoic magmatic events through protracted reactivation, spatial and geometric relationships between the magmatic provinces and tectonic fabric. The ENE-WSW trending Ocean fracture zones centred on the early Jurassic FLC and the angular relationship with the Permo-Triassic NE trending Guinea Belt and the Jurassic-Triassic NW-SE trending coast-parallel dykes, suggest that Sierra Leone-Liberia continental margin evolved as an obliquely-sheared, rift-rift-transform passive margin during Mesozoic continental breakup. Locally, the main fracture zones correspond to Babadorie-Orugu and Samcofam valleys.

Excluding the Cameroon volcanic line-associated with heat flows, most of West Africa has been seismically inactive, which is related to the underlying stable and canonised shields (Goki et al. 2020). Instability is only experienced at the eastern fringes, where older rocks were rejuvenated by orogenies created by the $600 \mathrm{Ma}$ Pan-African event. Sierra Leone is placed at an appreciable distance from the transform faults, and as such, there has been no record of tremor and any form of seismic activities.

\section{Methodology}

\section{Field survey}

The field surveys were preceded by analysing Google Earth images (earth imagery -accessed in 2019), which generated preliminary information on the landslides. The fieldwork took place over 5 days (between August and November in 2019) alongside an aerial survey conducted by Track Your Build (TYB, 2019), Sierra Leone Limited. UNOPS contracted them to join in on an assessment of the Madina landslide by the ONSTechnical Pillar team. At least a day was spent on each of the three landslide sites on field observations and mapping of the scars' geometric configuration, which depends on the terrain conditions.

Landslide bodies were mapped from crown to toe of rupture, applying a similar approach presented by Aleotti and Chowdhury (1999) and Igwe and Una (2019). Each slide's centre coordinate was determined using a Garmin eTrex-10 Geographic Positioning System (GPS) receiver using Universal Transverse Mercator (UTM) Zone 28 N, WGS 1984 as the standard reference system. Additional GPS coordinates were collected at the landslide scars' toe and margins using the same method mentioned above. The slides were described and classified following Cruden and Varnes (1996) and Hungr et al. (2001), based on their morphological characteristics. The slide area $\left(\mathrm{A}_{\mathrm{L}}\right)$, perimeter $\left(\mathrm{P}_{\mathrm{L}}\right)$, width $\left(\mathrm{W}_{\mathrm{L}}\right)$, length $\left(\mathrm{L}_{\mathrm{L}}\right)$ and scarp height $\left(\mathrm{H}_{\mathrm{S}}\right)$ were obtained by tracking landslide scars with a GPS and a $100 \mathrm{~m}$ graduated surveyor's tape, which validated those derived from Google EarthPro. The volume $\left(\mathrm{V}_{\mathrm{L}}\right)$ of displaced debris or generated material was estimated applying the method presented by Adegbe et al. (2014).

During the post landslide geological surveys, hand samples of rocks were described, and geological structures (cracks/fractures, joints and faults) within the landslide area were identified and reconstructed. Handlens (lobe) enhanced mineral identifications, and the discontinuities' location on the landslide main bodies and adjacent places were recorded. Their attitudes (strike direction, dip angle and dip directions) were determined using a Silva compass and clinometer. These lineaments were compared with the regional lineament distribution map of Freetown, produced by using automatic alignment identification tools from data provided by Cynthia Linero Molina and the British Geological Surveys (BGS). They are believed to be closely associated with intraplate and plate marginal reaction of pre-existing structures during the Mesozoic events. Other recorded features/parameters are layering and dip of rocks, weathering pattern and depth, boulder dimensions and soil types.

The landslide geomorphic features such as slope angles, slope aspects and elevations, head scarp, landslide height (the difference between the upper slope (crown) and slope base (toe) elevations) were determined using the Silva-type compass/clinometer, contour maps and the handheld GPS. This method's slope gradient was validated by the result of $2 \mathrm{D}$ orthomosaic analysis for the Madina landslide, which generated a similar slope angle range. These data present information necessary for understanding the susceptibility of the land surfaces affected by the slides. Finally, a schematic cross-section was drawn for each landslide in the field to display a 
better understanding of the morphology and representation of underlying geology and tectonic fabrics. The Digital Elevation Model (DEM) established the relationship between the surface elevation and the slide distribution.

\section{Laboratory tests and data analyses}

Tests were conducted on representative rock (grab) samples and the resulting landslide-prone soils in laboratories at the National Minerals Agency (NMA) and the respective Department of the Sierra Leone Road Authority (SLRA). The rock samples were cut into two halves using a slab cutter, with one-half used to prepare thin sections of $30-\mu \mathrm{m}$ thickness and the other half used for hand-held X-Ray Fluorescence (XRF) analysis. Bulk samples were collected from each of the landslide areas at a depth of about $1.5 \mathrm{~m}$ for the soil tests, such that the matrix excluded boulders and cobbles. They were used for the determination of particle-size distribution (PSD) using the sieve method. The consistency limits of each sample's fine were obtained by applying the Casagrande method and distinguished as either clay or silt using the
Casagrande plasticity chart. The laboratory-derived Atterberg Limits, together with the Cassagrade plasticity chart, aided the landslide-prone soils' classification according to EN ISO 14688-2:2018 (Geotechnical investigation and testing - Identification and classification of the soil) as presented in Table 3 .

The thin sections were analysed using a Carl Zeiss Polarizing Microscope-Axioscope A1 to evaluate their mineralogy, texture and structural characteristics. The XRF determined the elemental percentages in each of the rock samples. Together with other field and laboratory-derived data, this information was used to generate a detailed geologic map of the landslide area and surroundings using the Quantum GIS (QGIS) software. This Petrological characterisation formed the basis for assessing the various landslide area's underlying lithology and their relationship with the landslide occurrences. Using the same software, DEM was created by digitising the $20 \mathrm{~m}$ contour lines of the map with a spatial resolution of $33 \mathrm{~m}$ maintained. The relationship between the slides and land surface characteristics (e.g. elevation in this case) was established by plotting their GPS point coordinates on the DEM.

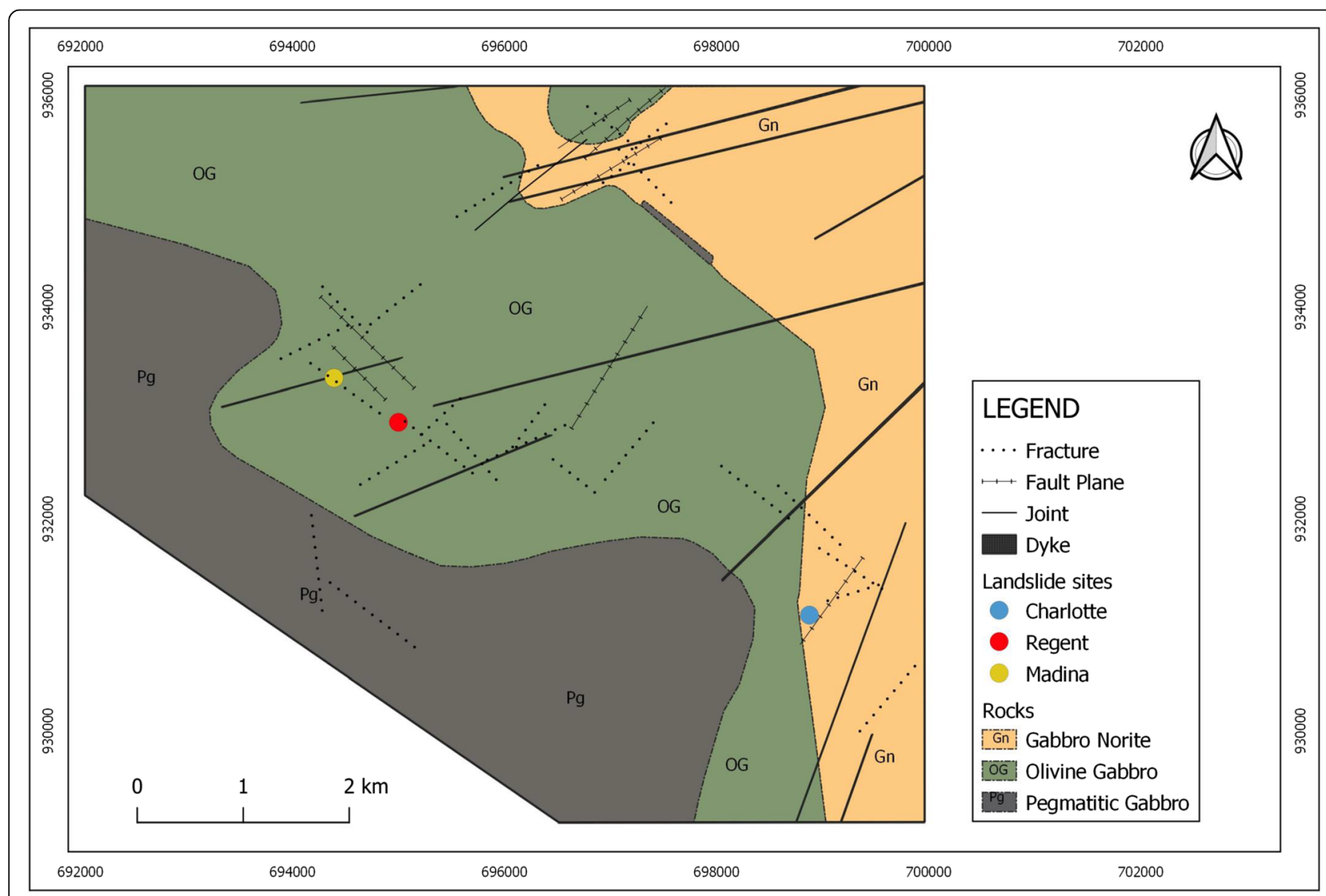

Fig. 3 Relationship between the landslides and the geology (rock types and discontinuities) 


\section{Results and discussions}

Geology, tectonics (structural discontinuities) and geomorphological characteristics

\section{Geological characteristics}

Norite and Olivine gabbro of the Freetown Layered Complex underlie the landslides (Fig. 3). Norite is the bedrock for the Charlotte landslide whilst olivine gabbro (medium-grained rock) underlies the Regent and Madina landslides. Both these rocks have a dip of about $64^{\circ}$ in the NNE direction. The norites are usually coarsegrained, whilst the olivine gabbros have medium-grains. The norites are usually weakly foliated. Dolerite, which is texturally and mineralogically distinct, is well exposed at the Madina landslide and occurs as discordant bodies within the host rock (Fig. 3). They dip between $20^{\circ}$ and $40^{\circ}$ in the southwest direction.

The norite consists of plagioclase (62.5\%), pyroxenes (30\%) with augite and clinopyroxene constituting $28.5 \%$ and $1.5 \%$ respectively, iron oxides (5\%), and others (2.5\%) (Fig. 4). About 95\% of the pyroxenes are augites (orthopyroxene), showing parallel extinction, and clinopyroxenes make up about $1.5 \%$. The pyroxenes and olivines are subhedral, and a section from the Madina landslide shows anhedral olivine grains. The Olivine gabbro consists of plagioclase (40\%), Olivine (30\%), pyroxene (20\%), mainly clinopyroxene, opaque minerals (4\%) and others (6\%) (Fig. 4). The pyroxenes and olivines display subhedral grain boundaries.
According to the XRF analysis results, the Regent and Madina landslides' bedrocks have relatively higher iron content and lower silica $(\mathrm{Si})$ and aluminum (Al) than the Charlotte landslide (Table 1). The elemental distribution within the soil, especially $\mathrm{Fe}$ and, to a lesser extent Manganese influences the soil colour (Owens \& Rutledge 2005).

The bedrocks of the landslides and their constituent mineral types are prone to rapid and deep chemical weathering by hydrolysis, to produce weakened clay-rich fractured rocks and soils. The weathering profiles have variable depths that are visible at the landslides' ridge tops. They are estimated at $3.5 \mathrm{~m}, 12 \mathrm{~m}$ and $1.3 \mathrm{~m}$ at Charlotte, Regent and Madina landslides, respectively. The specifics of both flanks of each of the three slides also differ in pattern and thickness. For instance: Charlotte east flank, the adjacent second bench is $\approx 18 \mathrm{~m}$ thicker (Fig. 5a); the Regent east flank has a relatively thin regolith ranging from 1 to $5 \mathrm{~m}$ (Fig. 6a), and Madina shows thicker weathering at both landslide flanks than the crown (headwall) (Figs. 7a).

Generally, the soil types covering all the landslide areas are similar and formed directly from the chemical alteration of the parent gabbroic rocks. They are gravelly and ferralitic soils with shallow soils on moderate to high relief hills. Field logging and particle-size distribution (PSD) tests, conducted on the soil at the SLRA Materials department laboratory, yielded the results in Table 2.

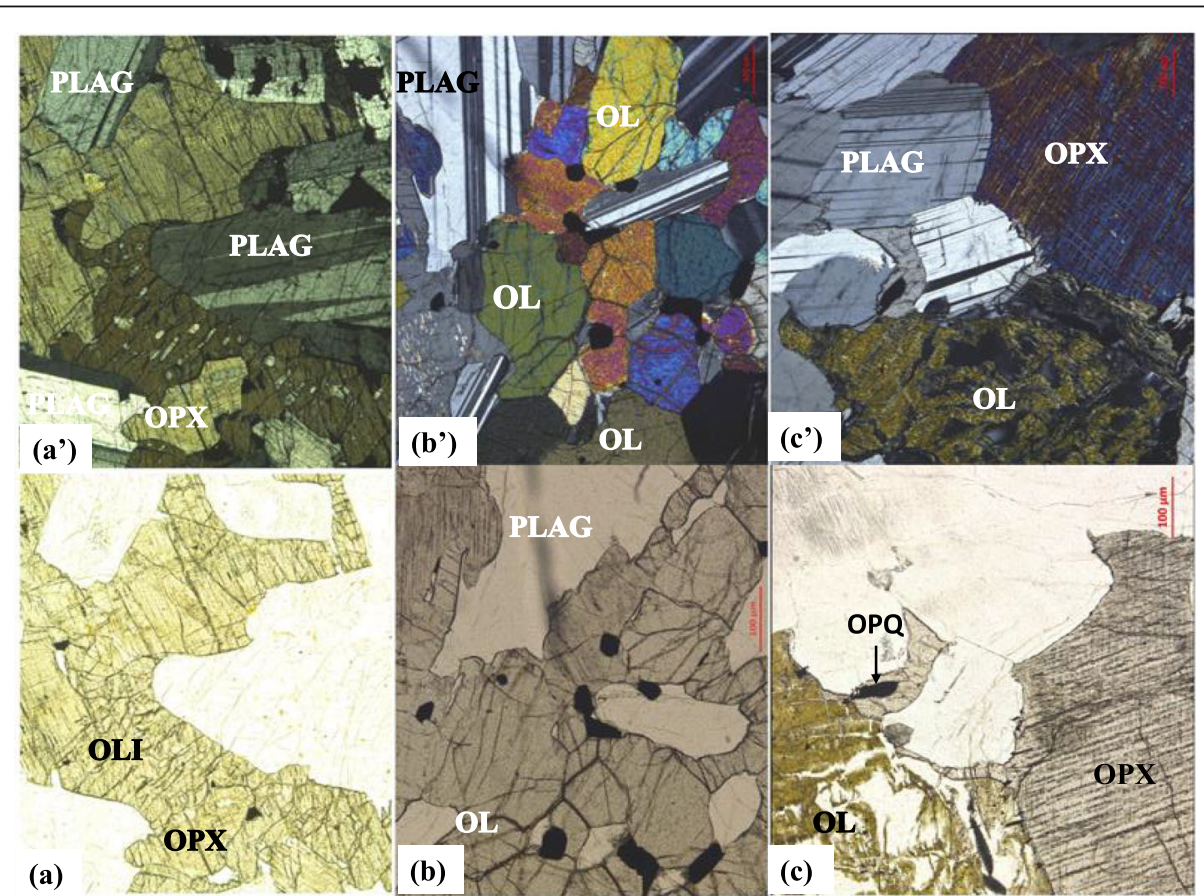

Fig. 4 Thin sections of the rock types underlying the landslide areas (Magnification: X5). a-a" norite (Charlotte); (b-b') Olivine gabbro (Regent); (cc') Olivine gabbro (Madina). The top images are under cross-polarization, whilst the bottom ones are under plane polarization. OL: Olivine; OLI: Olivine with cracks and plagioclase inclusions; OPX: Pyroxene; Opq: Opaque minerals; PLAG: Plagioclase 
Table 1 Handheld-XRF analysis results of rock samples from the three slides

\begin{tabular}{llll}
\hline $\begin{array}{l}\text { Landslide (Sample ID) } \\
\text { Rock type }\end{array}$ & $\begin{array}{l}\text { Charlotte Landslide (S1-CH) } \\
\text { Norite }\end{array}$ & $\begin{array}{l}\text { Regent Landslide (S2-RT) } \\
\text { Olivine gabbro }\end{array}$ & $\begin{array}{l}\text { Madina Landslide (S3-MD) } \\
\text { Olivine gabbro }\end{array}$ \\
\hline Elements (\%) & & & 42.89 \\
LE (Light Elements) & 45.67 & 46.50 & 22.64 \\
Si & 23.08 & 22.80 & 19.58 \\
Ca & 15.27 & 16.47 & 8.15 \\
Al & 11.83 & 9.54 & 4.57 \\
Fe & 2.40 & 3.31 & 1.57 \\
Mg & 0.75 & 0.97 & 0.60 \\
Others (Ti, Mn, Sr, V, Ni,Cu, Zn, Th, Nb, Zr) & 1.00 & 0.41 & \\
\hline
\end{tabular}

The PSD analysis for the Regent landslide is similar to the one reported by Redshaw et al. (2019). The fine (clay and silt) content slightly exceeds that of the gravel, and this situation increases for the Charlotte and Madina landslides than the Regent landslide.

The PSD analyses, coupled with information on the consistency limits (Fig. 8) of the soil samples, have enabled soil distinction and consequently influenced the soil type (Table 3). The thickness of soil and rock weathering profiles at the three sites is locally affected by bedrock texture, geochemistry, mechanical discontinuities (joint pattern, faults and shears) and the degree/depth of lateralisation and saprolite development (Redshaw et al., 2019). Not only do they vary in colour and thickness, embedded in them are boulders of varying diameters, implying the effects of joint patterns on weathering. This is much pronounced at the head scarp (crown) of the Regent landslide.

\section{Tectonic characteristics (structural features / tectonic fabrics)}

Surface discontinuities and lineaments are tectonic features used to describe fractures/cracks joints, and faults as these linear structures are a mirror image of subsurface conditions (O'Leary et al., 1976). The formation of most of these tectonic fabrics on the landslides and their surroundings is related to intraplate and plate marginal reaction of pre-existing structures during the Mesozoic events.

Discontinuities on the Charlotte landslide scar are not exposed due to the growth of vegetation and sediment accumulation on relatively planar sections of the landslide area. However, springs/creeks in open joints, observed during field surveys are indicative of subsurface discontinuities. Similar studies have supported the link between groundwater and the presence of subsurface lineaments, which manifests on the surface as springs or water seepages in open joints (e.g. Lattman and Parizek 1964; Sander et al., 2005; Jha et al. 2007; and Al-Nahmi et al., 2016). They run closer to both flanks and beneath the second bench, with a general strike in the SW-NE direction, corresponding to the slope aspect. Pronounced on the eastern side is a longitudinal valley, which postdated the slide. Attached to the prominent joints represented as stream channels are minor networks (trellised) of open joints with water seepages especially during the

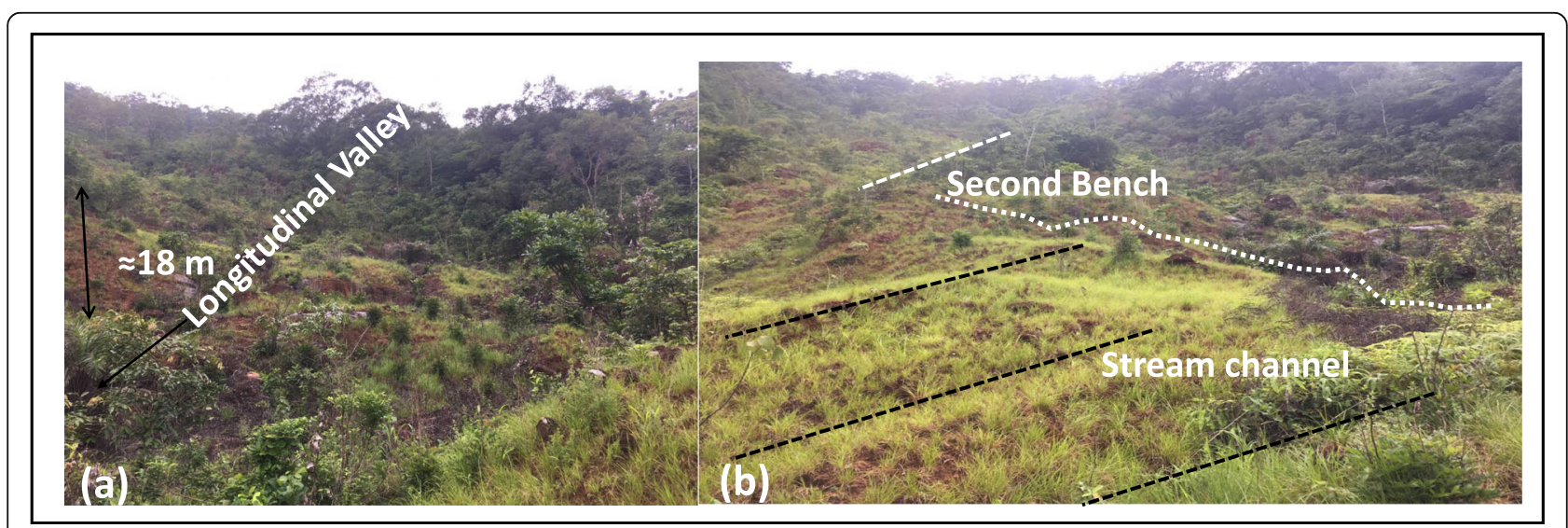

Fig. 5 Charlotte landslide conditions (a) Revegetated scars with regolith section at the right flank and prominent valley; (b) Lineament traces (white and black dashed lines) depicted by spring flows in open joints 


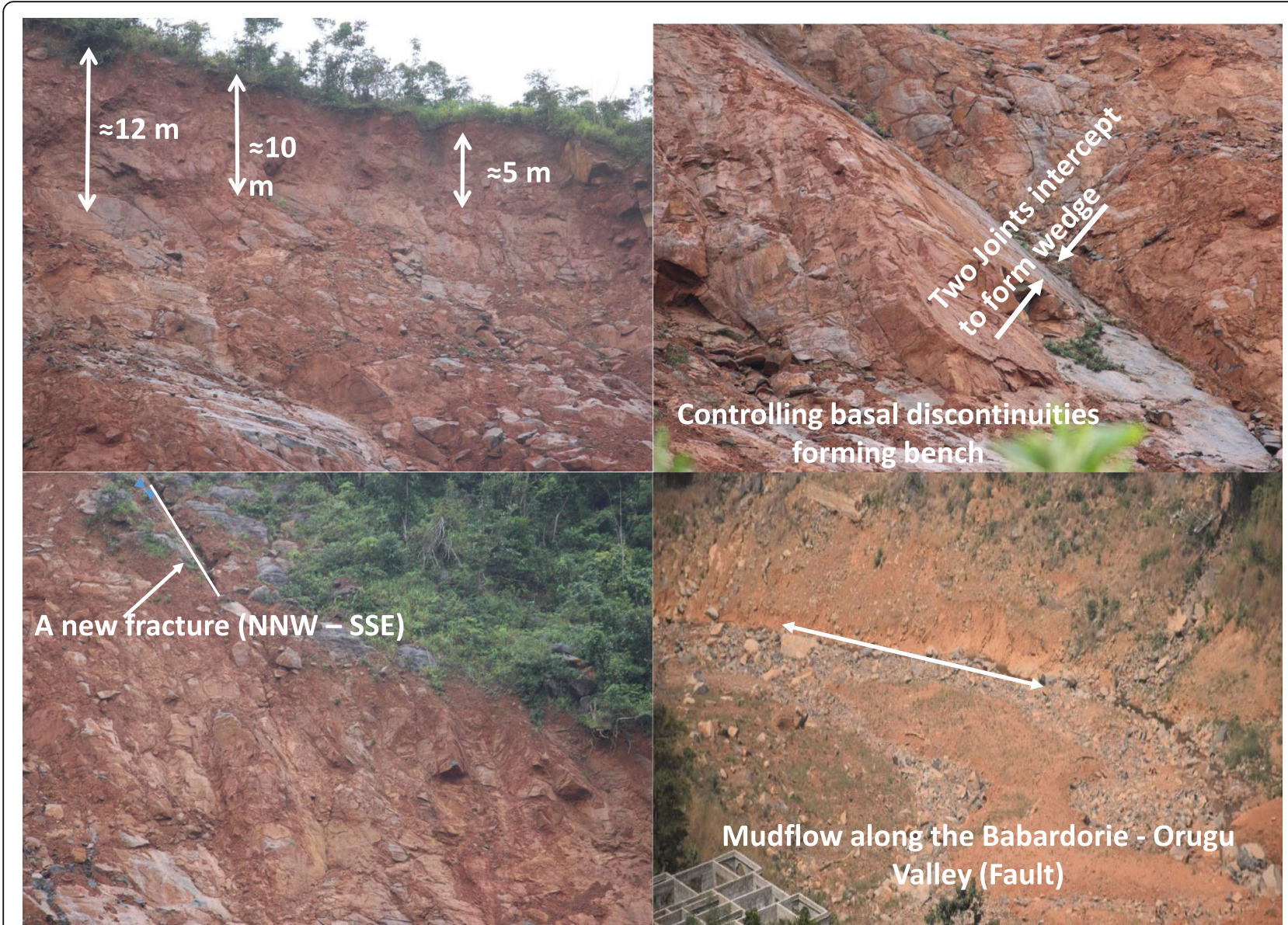

Fig. 6 Regent Landslide (a) variable weathering profile depth at ridge top; (b) different lineament pattern on slide body distinguishing the upper from the middle scar. The NNW-SSE marginal lineament represents a potential failure surface

rainy season. The water seepages were noted spouting out on the slide's body, and this situation was confirmed to be seasonal by residents of the Charlotte community. The lineaments were traced and represented as black and white solid dashed lines in Fig. 5b.
The Regent landslide is characterised by several discontinuities (dense lineaments) particularly on the main scarp, with the most prone zone having WNW-ESE weathered fractures. The joints are open, have variable dip amounts (15-40 degree NNE), and the orientations

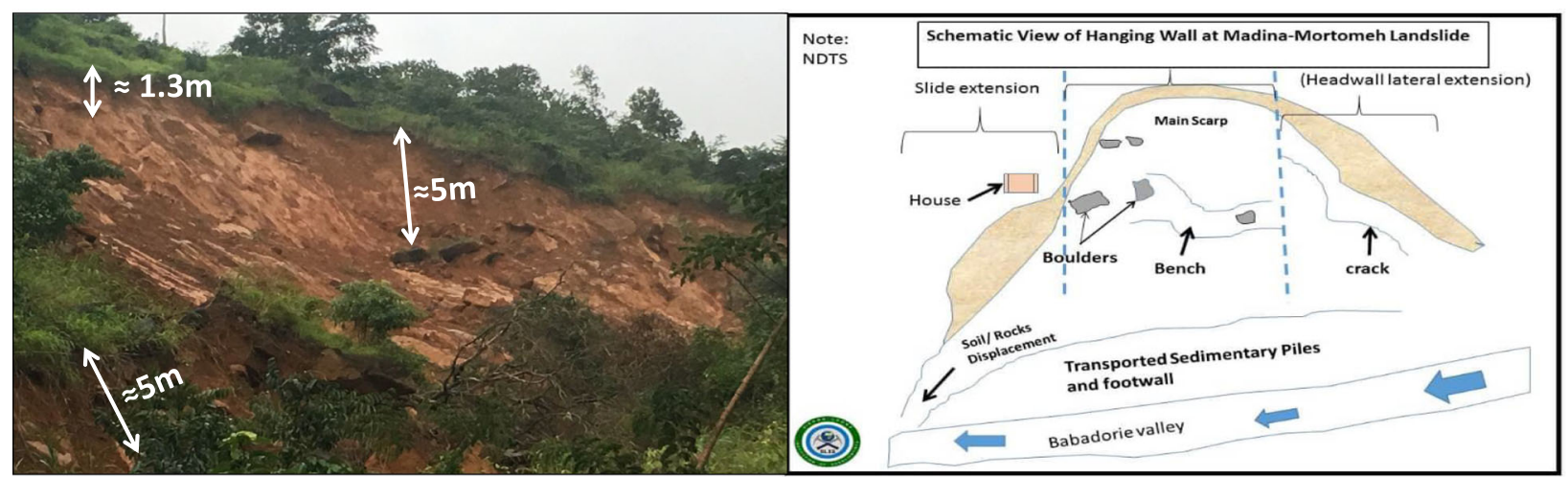

Fig. 7 Madina Landslide (a) lateral movement of the headwall along pre-slide shallow lineament, which disappear on the scar surface; (b) welllabeled sketch of the plan view 
Table 2 Particle-Size distribution analysis on soil samples of the three landslides

\begin{tabular}{llll}
\hline Landslide ID & Percentage of Particles (\%) & & Fines \\
\cline { 2 - 4 } & $\begin{array}{l}\text { Gravel } \\
(\mathbf{6 3} \mathbf{~ m m}-\mathbf{2 ~ m m})\end{array}$ & $\begin{array}{l}\text { Sand } \\
(\mathbf{2 ~ m m ~ - ~ 0 . 0 6 3 ) ~}\end{array}$ & $\begin{array}{l}<.063) \\
\text { Charlotte Landslide (S1-CH) }\end{array}$ \\
Regent Landslide (S2-RT) & 18.9 & 40 & 41.1 \\
Madina Landslide (S3-MD) & 31 & 35 & 34 \\
\hline
\end{tabular}

are parallel to the slope face (NNE-SSW). These linear fabric elements are consistent with the weathered sheet joints described by Redshaw et al. (2019), which led to the combination of translational (planar) and wedge sliding along discrete pre-existing bedrock discontinuities (Fig. 6b). The marked change observed in the dip and joint patterns differentiates the upper from the lower main scarp, and they may have effectively daylighted at the mid-slope to form a bench of $200 \mathrm{~m}$ wide. Water seepages coming out from the depletion zone, in open joints/ fractures were observed during field exercises. Beneath the landslide's main scarp is a weathered NNE joint/fault zone with a dip between 45 and 50 degrees. A new fracture (NNW-SSE) is present adjacent to the main scarp on the western flank (unaffected part of the west flank slope) and extends from the hill's top to the subparallel bench. The fracture will most likely form the next sliding plane if triggered by the next event of rainfall (Fig. 6b).

Unlike the other slides, Lineaments/discontinuities are absent on the Madina landslide's main surface (Fig. 7a). This rainfall-triggered landslide occurred due to shallow colluvial soil and the tension cracks behind the slope's edge, and these do not persist on the scar after debris dislodge. The slide has had consistent failures along preexisting cracks that also extinct on the landslide's body. The failures caused lateral extension of the headwall/ flanks, which eventually generated shallow cracks on adjacent surfaces. A typical example is the WNW-ESE cracks (approx. $7 \mathrm{~m}$ apart) on the hill slope, running from below the structure (dwelling house) above $\left(8^{0} 44^{\prime}\right.$ Nand $13^{0} 23^{\prime}$ W) to the landslide area. These cracks are also found on the floor of the structure above, as seen in Fig. 9d. They are most likely to form the next temporary sliding plane for any subsequent earth movements. As failures occur, the cracks disappear on the slide surface, indicating that they are not deep-seated discontinuities in contrast with those on the other slide scars (joints and cracks are confined within the weathered zone).

Further field surveys in the Madina landslide's immediate surroundings (hilltop, adjacent slope areas and the landslide toe) uncovered multiple surface discontinuities on outcrops and soil (regolith). They are readily recognised on rocks with the occurrence of spring seepages. On the soil surface, they are perturbed by the soil's thickness, making their field distinction challenging. A significant fracture zone (1500 mm wide) was mapped trending in the ENE-WSW direction with an inclined

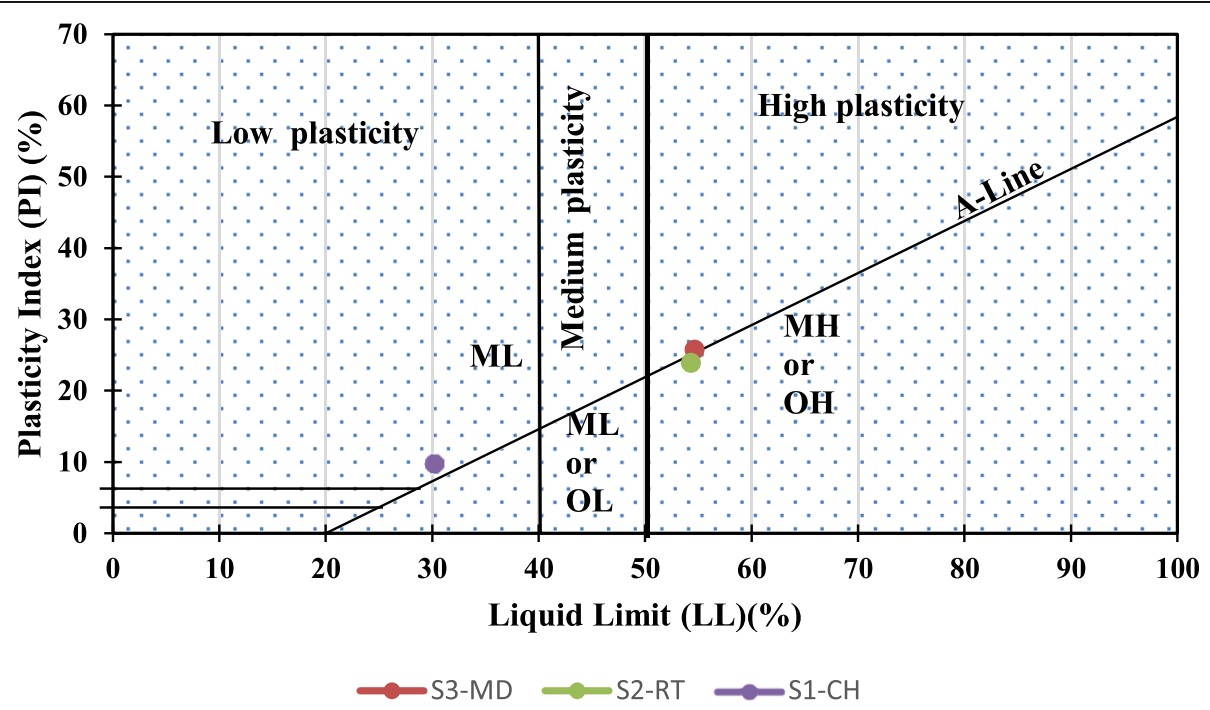

Fig. 8 Plasticity diagram distinguishing the fine-components of the slides' soil samples (- according to EN ISO 14688-2:2018) 
Table 3 Comparative GTG Characteristics of the Charlotte, Regent and Madina landslides

\begin{tabular}{|c|c|c|c|c|c|c|c|}
\hline Landslide ID & $\begin{array}{l}\text { Geological } \\
\text { Condition }\end{array}$ & $\begin{array}{l}\text { Geomorphological } \\
\text { (terrain) Condition }\end{array}$ & $\begin{array}{l}\text { Tectonic } \\
\text { Fabric }\end{array}$ & $\begin{array}{l}\text { Triggering } \\
\text { Factor }\end{array}$ & $\begin{array}{l}\text { Causative } \\
\text { Factor }\end{array}$ & $\begin{array}{l}\text { Soil } \\
\text { Type }\end{array}$ & Failure Type \\
\hline $\begin{array}{l}\text { Charlotte } \\
\text { Landslide (S1-CH) }\end{array}$ & $\begin{array}{l}\text { Rock type is } \\
\text { Norite with an } \\
\text { altitude of } 320 \\
\text { /40 SW. }\end{array}$ & $\begin{array}{l}\text { Elevation: } 270 \mathrm{~m} ; \\
\text { Slope angle: } 45^{\circ} \& \\
\text { Slope aspect: NE. } \\
\text { The } 4+\mathrm{m} \text { regolith } \\
\text { section on the right } \\
\text { forms immediate } \\
\text { post slide gully }\end{array}$ & $\begin{array}{l}\text { Longitudinal } \\
\text { open cracks } \\
\text { (NE-SW) on } \\
\text { both flanks of } \\
\text { the landslide } \\
\text { and trellised } \\
\text { open joints (< } \\
2.5 \mathrm{~cm} \text { ) with } \\
\text { running water } \\
\text { attached to } \\
\text { them. }\end{array}$ & $\begin{array}{l}\text { Rainfall, } \\
\text { Orugu } \\
\text { stream } \\
\text { erosion \& } \\
\text { urbanisation }\end{array}$ & $\begin{array}{l}\text { Rock joint } \\
\text { orientation } \\
\text { and Clay rich } \\
\text { layer towards } \\
\text { the bedrock. } \\
\text { This zone is } \\
\text { overlain by } \\
\text { porous and } \\
\text { permeable } \\
\text { regolith. }\end{array}$ & $\begin{array}{l}\text { Clayey } \\
\text { gravel } \\
\text { (Low } \\
\text { plasticity } \\
\text { clay) }\end{array}$ & $\begin{array}{l}\text { Composite type (Rock fall \& } \\
\text { Rotational) }\end{array}$ \\
\hline $\begin{array}{l}\text { Regent Landslide } \\
\text { (S2-RT) }\end{array}$ & $\begin{array}{l}\text { Olivine gabbro } \\
\text { (OG with } \\
\text { Dolerite dykes. } \\
\text { It is slightly } \\
\text { weathered to } \\
\text { fresh. } \approx 10 \mathrm{~m} \\
\text { upper part of } \\
\text { the rock is } \\
\text { weathered. } \\
\text { Rock altitude: } \\
320 / 40 \mathrm{SW}\end{array}$ & $\begin{array}{l}\text { Elevation: } 470 \mathrm{~m} ; \\
\text { Slope angle: } 60^{\circ} \& \\
\text { Slope aspect: N }\end{array}$ & $\begin{array}{l}\text { Jointed rock } \\
\text { with two } \\
\text { different joint } \\
\text { orientations or } \\
\text { more (NNW- } \\
\text { SSE \& NNE- } \\
\text { SSW) caused } \\
\text { two phases of } \\
\text { failures. }\end{array}$ & $\begin{array}{l}\text { Rainfall \& } \\
\text { urbanisation }\end{array}$ & $\begin{array}{l}\text { Geology } \\
\text { (Slide prone } \\
\text { zones linked } \\
\text { to } \\
\text { weathering } \\
\text { along WNW- } \\
\text { ESE joints) } \\
\text { and steep } \\
\text { slope }\left(>59^{\circ}\right)\end{array}$ & $\begin{array}{l}\text { Silty } \\
\text { gravel } \\
\text { (Highq12 } \\
\text { plasticity } \\
\text { silt) }\end{array}$ & $\begin{array}{l}\text { Translational \&Wedge- } \\
\text { typesliding(Broadly } \\
\text { deepseatedtranslationalslide }\end{array}$ \\
\hline $\begin{array}{l}\text { MadinaLandslide(S3- } \\
\text { MD) }\end{array}$ & $\begin{array}{l}\text { Olivine gabbro } \\
\text { intrudedby } \\
\text { Dolerite } \\
\text { dykes.Shallow } \\
\text { colluvial soil } \\
\text { of } \approx 1.3 \mathrm{~m} \text { at } \\
\text { headscarp, } \\
\text { which thickens } \\
\text { at flanks.Rock } \\
\text { altitude is290/ } \\
\text { 60NNE }\end{array}$ & $\begin{array}{l}\text { Elevation: } 200 \mathrm{~m} \text {; } \\
\text { Slopeangle: } 540 \& \\
\text { Slopeaspect: SW. } \\
\text { Debrisbulge at slide } \\
\text { toe andsedimentary } \\
\text { pile } 1 \mathrm{~m} \text { tothe NW- } \\
\text { SE valley(fault zone) }\end{array}$ & $\begin{array}{l}\text { No visible } \\
\text { lineaments } \\
\text { (fractures/cracks } \\
\text { and joints) on } \\
\text { the main body. }\end{array}$ & $\begin{array}{l}\text { Rainfall, } \\
\text { stone } \\
\text { mining \& } \\
\text { Slope } \\
\text { excavations }\end{array}$ & $\begin{array}{l}\text { Combination } \\
\text { of shallow } \\
\text { colluvial soil } \\
\text { and presence } \\
\text { of tension } \\
\text { cracks } \\
\text { behind the } \\
\text { edge of the } \\
\text { slope. }\end{array}$ & $\begin{array}{l}\text { Silty- } \\
\text { Clayey } \\
\text { gravel } \\
\text { (High } \\
\text { plasticity) }\end{array}$ & Shallow Translational slide \\
\hline
\end{tabular}

dip of 62 degrees. It post-dated the slide and now extends from the landslide bulge (formed by accumulated debris) down to the adjacent hill's foot, towards the Babadorie valley (A shear zone). Attached to it are numerous extensional cracks (tension gashes in soils, parallel and sub-parallel with the main lineament), with variable trends and width (102 $\mathrm{mm}$ to $155 \mathrm{~mm}$ ) formed by tension stresses and aggravated by the slide movements (Fig. 9 a-b). The depth of lineaments in Charlotte and Regent landslides' subsurface and all the landslides' immediate surroundings were not determined. Future studies in this regard will explore the recently countrywide airborne geophysical data to extract the lineaments and determine their depths within the Freetown-layered Complex.

\section{Geomorphological characteristics}

Three major geomorphologic elements are considered here, i.e. elevation, slope angle and slope aspect. In addition to the three parameters, the depth of head scarp (scarp height) and landslide height were determined and assessed as part of the geomorphological features documented in Table 4. Elevation and slope gradient vary along both flanks of the landslides, with the highest recorded values in the upper scarps and the lowest at the toes. Elevation ranges from $174 \mathrm{~m}-270 \mathrm{~m}$ for the Charlotte landslide, $267 \mathrm{~m}-470 \mathrm{~m}$ for the Regent landslide and $162 \mathrm{~m}-200 \mathrm{~m}$ for the Madina landslide. All elevation readings were taken regarding sea level, and in this case, they are all above sea level. The slope angles determined at the epicentres of Charlotte, Regent and Madina landslides are estimated as 45, 60 and 54 degrees, respectively (Table 3 ). Like the elevation and slope gradient, which vary among the three slides, the slope aspect also follows a similar trend with the Charlotte landslide initiated on the northeasterly facing slope. The Regent landslide affected the north-facing slope, and the south-western facing slope hosts the Madina landslide. The field elevation data are consistent with those extracted from the Digital Elevation Model (DEM) (Fig. 10b). The slope value obtained at the Madina depletion zone was validated by the slope result generated from the orthomosaic analysis done by Track Your Build (TYB). The analysis established the reliability in using a clinometer integrated into the Silva-type compass for slope angle determination.

In addition to the GTG descriptions, schematic crosssections or longitudinal sections through the slides have 


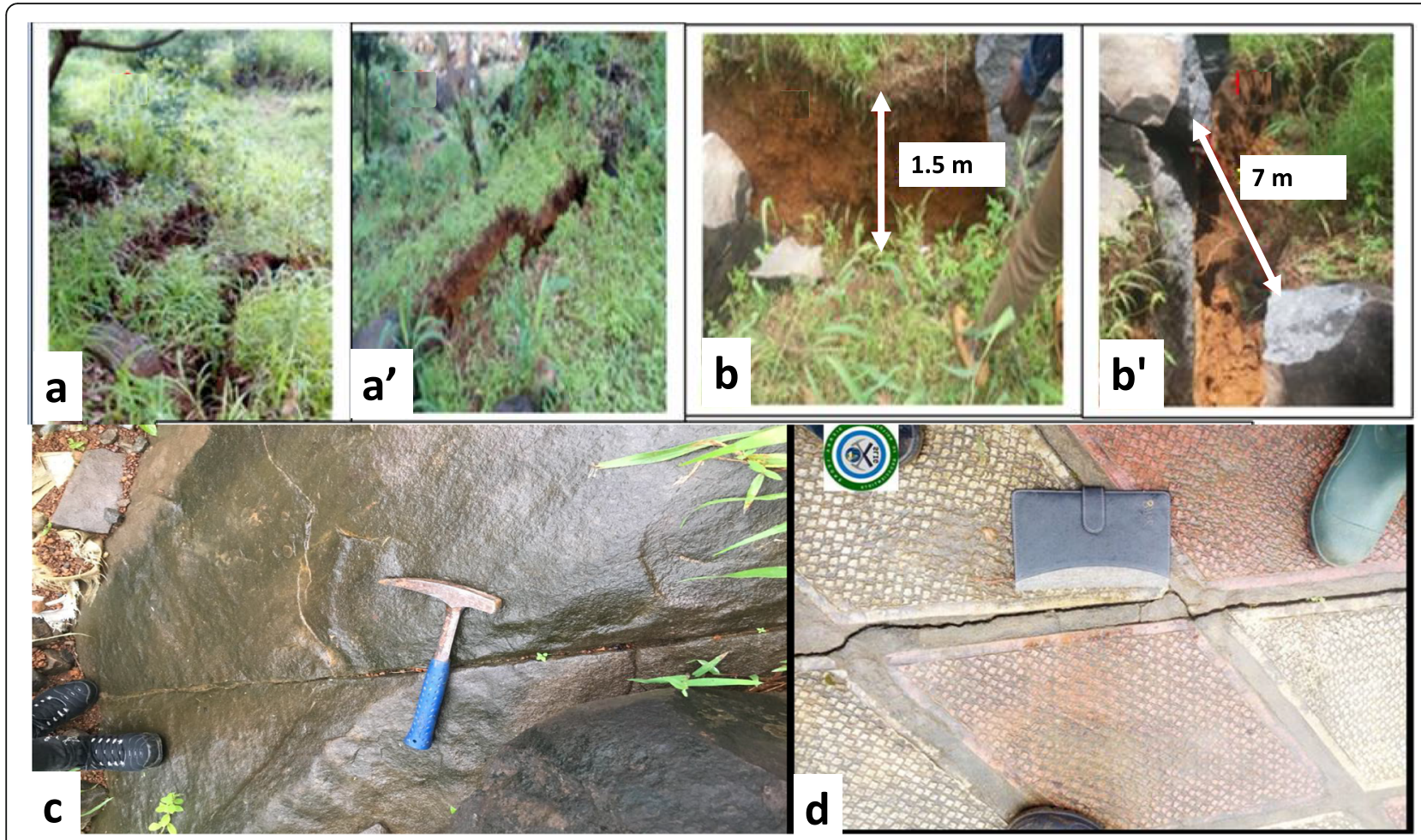

Fig. 9 Lineaments away from the main body of Madina landslide (a-a') tension cracks with varying widths in the north-west and adjacent to landslide; (b-b') major fracture zone with displaced rock fragments; (c) open joint on rock exposure adjacent Madina landslide area; (d) cracks on the floor of the building-35 $\mathrm{m}$ away from the epicenter of the landslide (Sillah et al., 2019)

revealed a visual morphological understanding of each of the landslides (Figs. 11, 12 \& 13). The schematic diagrams represent their underlying geology and tectonic fabrics/signatures on slide bodies, and the relationship between the slides and the linear fabrics are also shown in Fig. 3. The relationship between the slides and the linear fabrics is also shown in Fig. 3. The Regent landslide's cross-section is an updated/modified pre-existing crosssection of the Regent landslide done by Redshaw et al. and Lahai and Lahai Jr, 2019 (Fig. 12).

\section{Conclusions and recommendations \\ Conclusions}

Landslide characteristics constitute the required data needed to produce a landslide susceptibility map, necessary for engineering designs and overall disaster management. This work presents an understanding of the landslides' GTG characteristics, and they have been tabulated together with their geometric parameters for simplification and to enhance comparison.

The rock types played a significant role in the rainfalltriggered landslides, as they underwent intensive weathering to form thick soil profiles observed at landslide ridges and flanks/headwalls. However, the compositional variation of the underlying bedrocks is not the dominant factor influencing the distinct weathering patterns at the head scarps and flanks. For instance, there is a notable difference in the soil thicknesses (soil profile) at the Regent and Madina landslides' ridge tops despite them having the same composition. The Charlotte landslide has a thicker flank than the others' sides despite its lesser mafic composition (mafic silicates like olivine and

Table 4 Geometric Parameters of the Charlotte, Regent and Madina landslide

\begin{tabular}{|c|c|c|c|c|c|c|c|}
\hline Landslide ID & Slide length $(\mathrm{m})$ & Slide width (m) & Slide area $(\mathrm{m})$ & Slide Vol. $\left(\mathrm{m}^{3}\right)$ & Scarp height (m) & Landslide height (m) & Run-out dist. (m) \\
\hline Charlotte & 329 & 84 & 27,750 & 97,124 & 3.5 & 96 & 400 \\
\hline Regent & 499 & 200 & 99,759 & 598,556 & 6 & 203 & 6000 \\
\hline Madina & 72 & 265 & 19,053 & 24,769 & 1.3 & 38 & 148 \\
\hline Average & 300 & 183 & 48,854 & 240,149 & 4 & 112 & 2183 \\
\hline St. deviation & 215 & 92 & 44,299 & 312,490 & 2 & 84 & 3308 \\
\hline CV & 1 & 2 & 1 & 1 & 2 & 1 & 1 \\
\hline
\end{tabular}




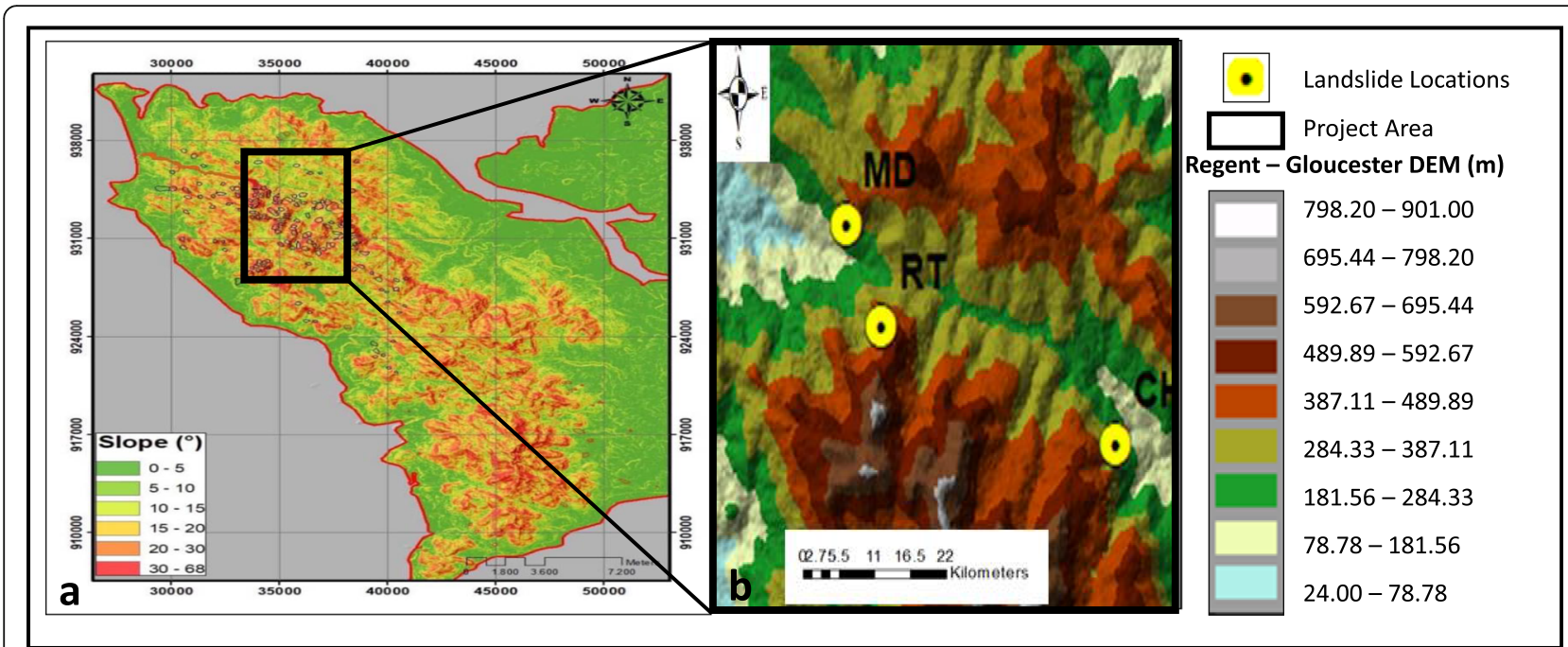

Fig. 10 a Regional Slope and historic landslide map of Freetown showing study area (Source: NMA, 2019); (b) DEM of study area projected from Fig. 10a -\{Charlotte (CH), Regent (RT) and Madina (MD) landslide

pyroxene tend to weather much faster than felsic minerals like quartz and feldspars). Soil thickness is linked to the weathering pattern, which is affected by the joint pattern. Such a joint-controlled weathering pattern is observed at the head scarps, with the soil profile containing submerged rounded and sub-rounded boulders/ corestones.
The lineaments on the landslide bodies and adjacent surfaces correspond to regional trends, and the margins and failure patterns are influenced by each landslide area's localised lineament pattern. They vary from one scar to the other in terms of their density, nature and characteristics, indicating different structural geological conditions. Unlike the Madina landslide, lineaments

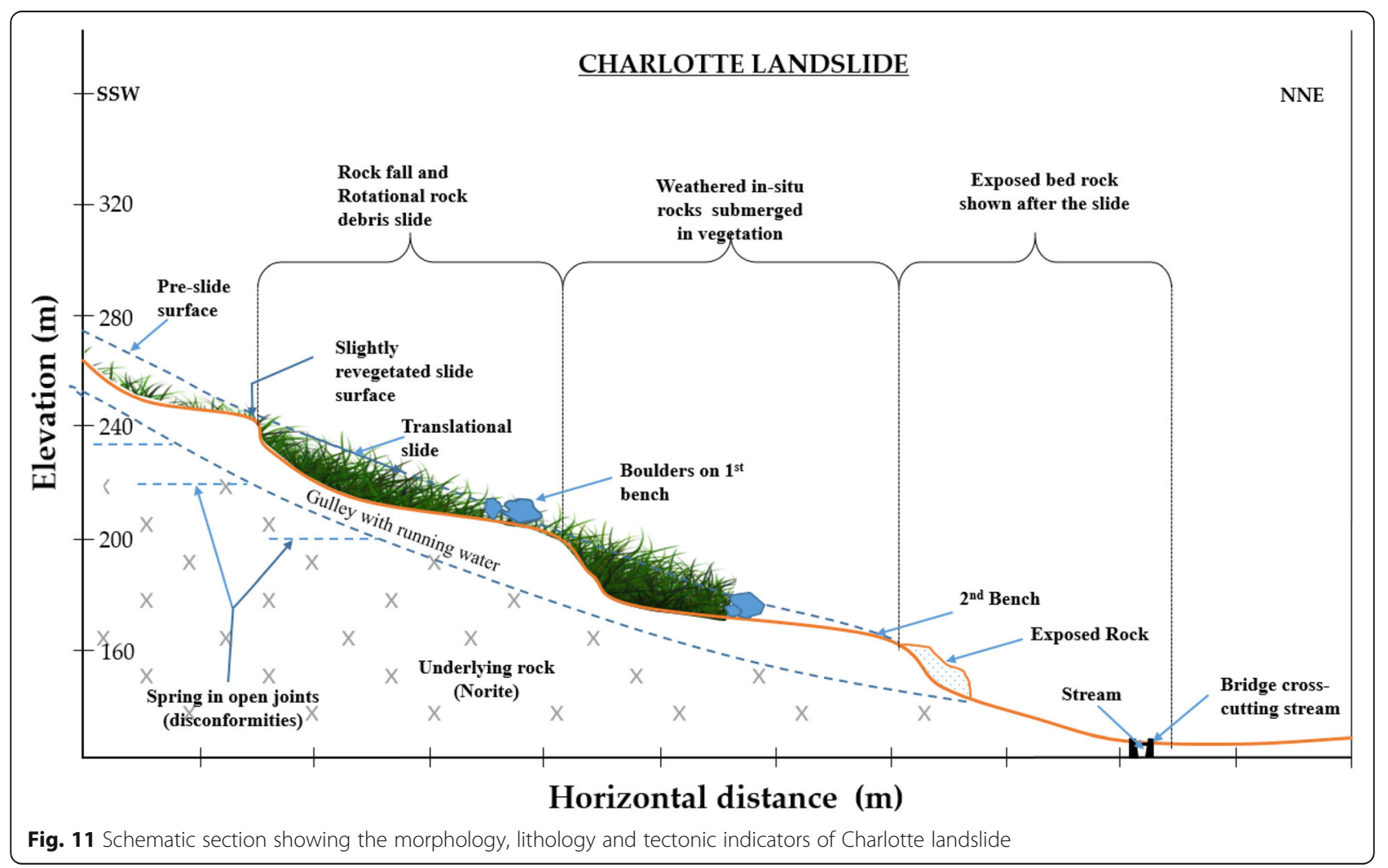



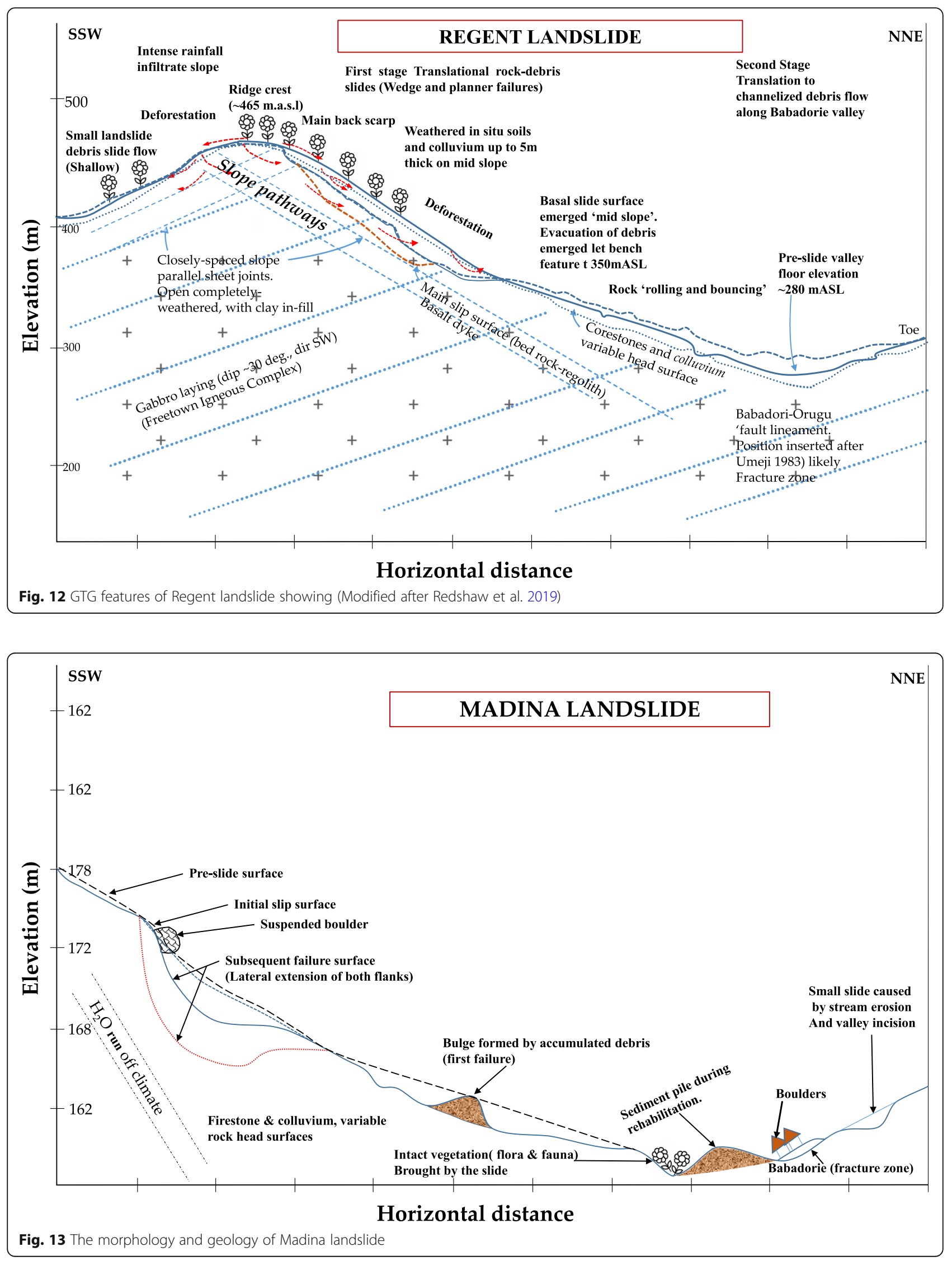
persist on the other landslides' bodies and seem to penetrate the subsurface. The Regent landslide's main scarp has dense lineaments from which water seepages drain from open joints during the rains. These springs represent the groundwater source, and together with the depth of rupture $(5-10 \mathrm{~m})$, they are deep-seated fractures. Similar open fractures with running water on the second bench are also observed on the Charlotte landslide. As noted by Redshaw et al. 2019, the basal controlling discontinuities may have effectively contributed to the formation of benches on the Charlotte and Regent Landsides.

The landslides occur on highland areas (> $200 \mathrm{~m}$ a.s.l) with steep gradient $>45$ degrees. These parameters are the most important geomorphological factors used for assessing slope stability, and they reduce along the slope and flanks from up (upper scarp) to down (toe). Excluding Madina landslide, relatively two wide benches $(11 \mathrm{~m}$ and $13 \mathrm{~m}$ in width) were formed at Charlotte landslide and one bench $(15 \mathrm{~m})$ at Regent slide. All the benches are sub-horizontal, creating a planar platform for accumulated boulders and debris.

\section{Recommendations}

Further work involving geotechnical drilling and investigation is required to provide deep-seated structural information (deep-seated fractures/cracks, joints and faults), knowledge of secondary minerals (e.g. clay) present in the joints and additional characterization of the slope soil/material. This would reveal their extent in the subsurface, and indicate the failure surface and threshold level for landslide occurrence. If available, the airborne geophysical data could be processed to extract the lineaments and estimate their depths in the subsurface.

The preparation of a landslide susceptibility map of the area using GTG characteristics and other factors is crucial for Landslide Disaster Management. This demarcates safe and unsafe zones suitable for engineering designs, and it will be useful for city planning.

The Global Environmental report in 2017 ranks Sierra Leone as the third most vulnerable country to the effects of climate change, evident by landslide and flood events every year. To minimise fatalities from these hydrorelated disasters such as this, the government should utilise funds from development partners to effectively establish Rain gauge stations at various zones within the Freetown complex. This generates information on the variation in rainfall density from which the threshold level for antecedent rainfall that may cause landslides can be determined. This information is vital in giving advice and early warning to appropriate authorities for intervention.

\section{Abbreviations}

Al: Aluminum; BGS: British geological surveys; DEM: Digital elevation model; EM-DAT: International emergency database; Fe: Iron; FLC: Freetown layered complex; GIS: Geographic information system; GLIDE: Global disaster identifier; GPS: Geographic positioning system; GTG: Geology, tectonics and geomorphology; LE: Light elements; NMA: National minerals agency; ONS: Office of national security; PSD: Particle-size distribution;

QGIS: Quantum GIS; Si: Silica; SLIG: Sierra leone institution of geoscientists; SLRA: Sierra leone road authority; TYB: Track your build; UNOPS: United Nations office for project services; UTM: Universal transverse mercator; XRF: X-Ray fluorescence; $\mathrm{S}_{1}-\mathrm{CH}$ : Charlotte landslide; $\mathrm{S}_{2}-\mathrm{RT}$ : Regent landslide; $\mathrm{S}_{3}$-MD: Madina landslide

\section{Acknowledgments}

The authors are grateful to the Directorate of Geological Surveys of the National Minerals Agency and the Sierra Leone Road Authority for the use of their facilities to conduct thin section analyses and laboratory soil tests respectively. These analyses were made possible through technical collaborations established between the University of Sierra Leone and these two institutions through the Heads of the Departments (HoD) of Geology and Geography. For this, we render our appreciation to these HoDs for such a laudable venture. Finally, many thanks go to the Sierra Leone Institution of Geoscientists (SLIG) and UNOPS, for conducting field reconnaissance at the Madina landslide, which contributed to some part of this study.

\section{Authors' contributions}

YAL collected all the remote and field data used in this manuscript under the supervision of KFEA. They prepared the soil samples for laboratory analyses and analyzed the laboratory-derived data and the data type mentioned above-using origin and Microsoft excel. They also submitted the first draft of the manuscript which included all the author contributions. YJ and IR contributed greatly to all works in the manuscript related to GIS (e.g. the production of the geological map, DEM and the inventory map). MK prepared and analysed the thin sections, and also the XRF analyses of the soil samples. All the authors read and approved the final manuscript.

\section{Funding}

The authors financed the research work.

\section{Availability of data and materials}

The data used and /or analyzed during the current study are available from the corresponding author on reasonable request.

\section{Declarations}

Ethics approval and consent to participate

Not applicable.

\section{Consent for publication}

Not applicable in this section.

Competing interests

Not applicable here.

\section{Author details}

'Department of Geology, Fourah Bay College, University of Sierra Leone, Freetown, Sierra Leone. ${ }^{2}$ National Minerals Agency, Freetown, Sierra Leone. ${ }^{3}$ Sierra Rutile Company Limited, Freetown, Sierra Leone.

Received: 28 February 2020 Accepted: 25 May 2021

Published online: 19 July 2021

\section{References}

Adegbe M, Agbor A, Onoduku US, Asema Al, Unubi AS, Inyang EB (2014) Determination of the volume of debris from Yingxiu landslides, Southwest China: geomorphological and field observation approaches. J Nat Sci 2:95-105

Afungang RN (2015) Spatiotemporal probabilistic assessment of landslide Hazard along Bamenda Mountain region of the Cameroon volcanic line. Dissertation, University of Yaoundé I 
Aleotti P, Chowdhury R (1999) Landslide hazard assessment: summary review and new perspectives. Bull EngGeol Environ 58(1):21-44. https://doi.org/10.1007/ s100640050066

Al-Nahmi F, Alami OB, Baidder L, Khanbari K, Rhinane H, Hilali A (2016) Using Remote sensing for lineament Extraction in Al Magbrabah area-Hajjah, Yemen. The International Archives of the Photogrammetry, remote sensing and Spatial Information Sciences, volume XLII-2/W1, 2016). $3^{\text {rd }}$ International Geo Advances workshop, 16-17 October 2016, Istanbul, turkey

Arup, BGS, JBA \& INTEGEMS (2018) Sierra Leone Multi-City Hazard review and risk assessment. A report produced for the World Bank Global Facility for Disaster Reduction and Recovery and the Government of Sierra Leone. The World Bank

Asma D (2013) Landslides in and sediment production from the Gilgel gibe catchment. KU Leuven and VrijeUniversiteit Brussel, SW Ehiopia

Borrelli L, Ferlisi GNS, Peduto D, Nocero SD, Gulla G (2018) Geology, slow-moving landslides, and damages to building in the verbicaro area (North-Western Calabria region, southern Italy). J Maps 14(2):32-44. https://doi.org/10.1080/1 7445647.2018.1425164

Bouhadad Y, Benhamouche A, Bourenane H, Ouali AA, Chikh M, Guessoum N (2010) The Laalam (Algeria) damaging landslide triggered by a moderate earthquake (mw=5.2). Nat Hazards 54:261-272. https://doi.org/10.1007/s 11 069-0099466-0

Bourenane H, Bouhadad Y, Guettouche MS, Braham M (2015) GIS-based landslide susceptibility zonation using bivariate statistical and expert approaches in the city of Constantine (Northeast Algeria). Bull Eng Geol Environ. 74:337-355 http://dx. doi.org/https://doi.org/10.1007/s10064-014-0616-6

Bowles JF, Suárez S, Prichard HM, Fisher PC (2017) Weathering of PGE sulfides and Pt-Fe alloys in the Freetown layered complex, Sierra Leone. Minera Deposita 52(8):1127-1144. https://doi.org/10.1007/s00126-016-0706-4

Broeckx J, Vanmaercke M, Duchateau R, Poesen J (2018). A data-based landslide susceptibility map of Africa. Earth Sci Rev 185:102-121. https://doi/https://doi. org/10.1016/j.earsciev.2018.05.002

Broothaerts N, Kissi E, Poesen J, Van Rompaey A, Getahun K, VanRanst E, and Diels J (2012) Spatial pattern, causes and consequences of landslides in theGilgel Gibe catchment, SW Ethiopia, Catena. Elsevier 97:127-136. https:// doi.org/10.1016/j.catena.2012.05.011

Bruce I (2019) A preventable disaster: landslides and flooding disaster in Freetown, Sierra Leone. World Bank report published on Sustainable Cities

Callegaro S, Marzoli A, Bertrand H, Blichert-Toft J, Reisberg L, Cavazzini G, Jourdan F, Davies JHFL, Parisio L, Bouchet R, Paul A, Schaltegger U, Chiaradia M (2017) Geochemical constraints provided by the Freetown layered complex (Sierra Leone) on the origin of high-Ti tholeiitic CAMP magmas. J Petrol 58(9):18111840. https://doi.org/10.1093/petrology/egx073

Cerri RI, Reis FAGV, Gramani MF, Giordano LC, Zaine JE (2017) Landslide zonation Hazard: relation between geological structures and landslides occurrence in hilly tropical regions of Brazil. Ann Braz Acad Sci. http://dx.doi.org/https://doi. org/10.1590/0001-376520170224

Chalokwu Cl, Ripley EM, Park Y (1999) Oxygen isotopic systematics of an opensystem magma chamber:: An example from the Freetown Layered Complex of Sierra Leone. Geochimica et Cosmochimica Acta 63(5):675-85. https://doi. org/10.1016/S0016-7037(99)00098-8.

Chalokwu Cl (2001) Petrology of the Freetown-layered complex, Sierra Leone: part II magma evolution and crystallization conditions. J Afr Earth Sci 32: 519-540. https://doi.org/10.1016/S0899-5362(01)90112-5.

Che VB, Kervyn M, Ernst GGJ, Trefois P, Ayonghe S, Jacobs P, Van Ranst E, Suh SE (2011) Systematic documentation of landslide events in Limbe area (Mt Cameroon): geometry, controlling and triggering factors. Nat Hazards 59: $47-$ 74. https://doi.org/10.1007/s11069-011-9738-3

Chigira M (2006) Geological and geomorphological characteristics of landslides generated by the mid Niigata prefecture earthquake in 2004. J Jpn Soc Eng Geol https://doi.org/10.5/10/jjseg.46.115

Clarke H (2017) Hundreds killed in Sierra Leone mudslides. https://edition.cnn. com/2017/08/14/africa/sierra-leone-mudslide/index.html. Accessed 10 Nov 2019

Corominas J, Van Westen C, Frattini P, Cascini L, Malet J, Fotopoulou S, Catani F, Van Den Eeckhaut M, Mavrouli O, Agliardi F, Pitilakis K, Winter M, Pastor M, Ferlisi S, Tofani V, Hervás J, Smith J (2013) Recommendations for the quantitative analysis of landslide risk. Bull Eng Geol Environ 73(2):209-263

Cruden D, Varnes DJ (1996) Landslide types and process. In: Turner AK, Schuster $\mathrm{RL}$ (eds) Landslides investigation and mitigation. Special report 247.
Transportation Research Board. National Academy of Sciences, Washington DC, pp 36-75

Cui Y, Cheng D, Choi CE, Jin W, Lei Y, Kargel JS (2019) The cost of rapid and haphazard urbanization: lessons learned from the Freetown landslide disaster. Recent Landslide 16(6):1167-1176. https://doi.org/10.1007/s10346-01 9-01167-X

Dai FC, Lee CF, Ngai YY (2002) Landslide risk assessment and management: An overview. Eng Geol 64(1):65-87. https://doi.org/10.1016/50013-7952(01 )00093-X

Delmonaco G, Falconi L, Leoni G, Margottini C, Puglisi C, SpizziChino DL (2005) Multi-Temporal and Quantitative Geomorphological Analysis on the Landslide of Craco village (M118). Springer. https://doi.org/10.1007/3-540-2 $8680-2 \quad 13$

Ennih N, Liègeois JP (2008) The boundaries of the West Africa craton, with special reference to the basement of the Moroccan metacratonicAnti-atlas belt. Geol Soc Lond, Spec Publ 297(1):1-17. https://doi.org/10.1144/SP297.1

FCC (2014) The Environmental Assessment and Evaluation of Natural Disaster Risk and Evaluation of Natural Disaster Risk and Mitigation in Freetown. Urban Planning Project 2011-14, financed by the European Union. Freetown, Freetown City Council (FCC) and the Ministry of Lands, Country planning and the Environment (MLCPE)

Froude MJ, Petley D (2018) Global fatal landslide occurrence from 2004 to 2016. Nat Hazards Earth Syst Sci 18:2161-2181

Goki NG, Onwuka SA, Oleka AB, lyakwari S, Tanko IY, Kana AA, Umbugadu AA, Usman HO (2020) Preliminary geological evidence for multiple tremors in Kwoi, Central Nigeria. Geoenviron Disasters https://doi.org/10.1186/s40677-02 $0-00156-w$

Guzzetti F (2000) Landslide fatalities and the evaluation of landslide risk in Italy. Eng Geo 58(2):89-107. https://doi.org/10.1016/S0013-7952(00)00047-8

Hardwick D (2012) A mass movement classification for the southern Drakensberg. University of the Witwatersrand, South Africa

Hattori K, Cabri L, Hart SR (1991) Osmium isotope ratios of PGM grains associated with the Freetown Layered Complex, and their origin. contrib Mineral Petro. 109:10-18. https://doi.org/10.1007/BF00687197.

Hungr O, Evans SG, Bovis MJ, Hutchinson JN (2001) Review of the classification of landslides of the flow type. Environ Eng Geosci 7(3):221-238. https://doi. org/10.2113/gseegeosci.7.3.221

Igwe $O$ (2015) The geotechnical characteristics of landslides on the sedimentary and metamorphic terrains of South Nigeria. Geoenvironmental Disasters 2(1). https://doi.org/10.1186/s40677-014-0008-z

Igwe O, Una CO (2019) Landslide impacts and management in Nanka area, Southeast Nigeria. Geoenviron Disasters. Doi.org/https://doi.org/10.1186/s4 0677-1019-0122-z

INTEGEMS (2017) Update on Sierra Leone Hazard profile and capacity gap analysis. Final report prepared for United Nations development Programme (UNDP), Office of National Security, Sierra Leone meteorological agency (SLMA), environment protection agency-Sierra Leone (EPA-SL) and Ministry of Water Resources (MWR)

Jacobs L, Dewitte O, Poesen J, Maes J, Mertens K, Sekajugo J, Kervyn M (2016) Landslide characteristics and spatial distribution in the Rwenzori Mountains, Uganda. J Afr Earth Sci. http://dx.doi.org/https://doi.org/10.1016/j.jafrearsci201 6.05 .013

Jha M, Chowdhury A, Chowdary V, Peiffer S (2007) Groundwater Management and development by integrated remote sensing and Geographic Information Systems: Prospects and constraints. Water Resources Management. Dohttps://doi.org/10.1007/s11269-006-9024-4, 21, 2, 427, 467

Jin W, Cui Y, Wu S, Cheng D (2020) Ecological risk resonance of urbanization and its effects on geohazard disaster: the case of Freetown, Sierra Leone. Urban Ecosyst 23(5):1141-1152. https://doi.org/10.1007/s11252-020-00989-1

Kimaro DN, Poesen J, Deckers JA, Msita HB (2010) Magnitude and severity of channel irrigation-induced landslides on different cultivation systems in the vegetable growing area of the Uluguru mountains. In: Nardali ET (ed) No-till farming: effects on soil, Pros and Cons and Potential. Agriculture Issues and Policies Series Nova Science Publishers, Inc, Tanzania, pp 129-144

Knapen A, Kitutu MG, Poesen J, Breugelmans W, Deckers J, Muwanga A (2006) Landslides in a densely populated county at the foot slopes of mount Elgon (Uganda): characteristics and causal factors. Geomorphology 73(1-2):149-165. https://doi.org/10.1016/j.geomorph.2005.07.004

Kumar K, Jangpangi L, Gangopadhyay S (2014) Highway vs landslides and their consequences in Himalaya. In: Sassa K, Canuti P, You Y (eds) Landslide Science for a safer Geoenvironment. Springer, Berlin/Heidelberg, Germany, pp 389-395 
Lahai YA, Lahai PS Jr (2019) Geological context and statistical assessment of the impacts of sugarloaf twin disasters, in Western Sierra Leone. J Geoscience Environ Prot 7:226-247. https://doi.org/10.4236/gep.2019.76017

Lattman LH, Parizek RR (1964) Relationship between fracture traces and the occurrence of groundwater in carbonate rocks. J Hydrol 2(2):73-91. https:// doi.org/10.1016/0022-1694(64)90019-8.

Lupiano V, Rago V, Terranove OG, lovine G (2018) Landslide inventory and main geomorphological features affecting slope stability in the Picentino river basin (Campania southern Italy). J Maps https://doi.org/https://doi.org/10.1 080/17445647.2018.1563836, 15, 2, 131, 141

Maertens M (2016) Landslide susceptibility mapping for the Mt Elgon region, Uganda. In: KU Leuven and Vrije Universiteit Brussel

Maes J, Kervn M, Hontheim A, Dewitte O, Jacobs L, Mertens K, Vanmaercke M, Vranken L, Poesen J (2017) Landslide risk reduction measures: a review of practices and challenges for the tropics. Progress in physical geography. Earth Environ. 41(2):191-221. https://doi.org/10.1177/0309133316689344.

Maki Mateso JC, Dewitte O (2014) Towards an inventory of landslide processes and the elements at risk on the rift flanks west of Lake Kivu DRC. Geo-EcoTrop 38(1):137-154. https://doi.org/10.1177/0309133316689344

Moeyersons J, Trefois P, Nahimana L, Ilunga L, Vandecasteele I, Byizigiro V, Sadiki S (2010) River and landslide dynamics on the western Tanganyika rift border, Uvira, D.R. Congo: diachronic observations and a GIS inventory of traces of extreme geomorphologic activity. Nat Hazards 53:291-311 http://dx.doi.org/1 0.1007/s11069-009-9430-z

Monsieurs E, Jacobs L, Michellier C, Tchangaboba JB, Ganza GB, Kervyn F, Mateso JM, Bibentyo TM, Buzera CK, Nahimana L, Ndayisenga A, Nkurunziza P, Thiery W, Demoulin A, Kervyn M, Dewitte O (2018) Landslide inventory for hazard assessment in a data-poor context: a regional-scale approach in a tropical African environment. Landslides 15(11):2195-2209. https://doi.org/10.1007/s1 0346-018-1008-y

Msilimba GG (2010) The socioeconomic and environmental effects of the 2003 landslides in the Rumphi and Ntcheu districts (Malawi). Nat Hazards 53: 347 360. https://doi.org/10.1007/s11069-009-9437-5

Msilimba GG, Holmes PJ (2010) Landslides in the Rumphi District of northern Malawi: characteristics and mechanisms of generation. Nat Hazards 54(3): 657-677. https://doi.org/10.1007/s11069-009-9495-8

Nakano M, Cigira M, Lim C, Gajam S (2015) Geomorphological and geological features of the collapsing landslides induced by the 2009 Padang earthquake-10 $0^{\text {th }}$ Asian $\mid$ Regional Conference of IAEG

Ndyanabo S, Vandecasteele I., Moeyersons J, Trefois P, Ozer A (2011) Vulnerability mapping for sustainable hazard mitigation in the city of Bukavu. In: South Kivu DR Congo Presentation Outline

Ngeku WM, Mathu EM (1999) The El-Nino-triggered landslides and their socioeconomic impact on Kenya. Environ Geol 46:1123-1133

Ngeku WM, Nyamai CM, Erima G (2004) The extent and significance of mass movements in eastern Africa: case studies of some major landslides in Uganda and Kenya. Environ Geol 46:2113-1133

Nibigira L, Draidia S, Havenith H (2013) La vallée du rift est-africain face aux risquesgravitaires: casde Bujumbura (Burundi). Troisièmes Journées Aléas Gravitaires, 2013 Sep 17-18. (Grenoble (France))

Nugraha H, Dhandhun W, Dipayana GA, Cahyadi A, Mutaqin BW, Larasati A (2015) Geomorphometric characteristics of landslides in the Tinalah watershed, Menorch Mountains, Yogyakarta, Indonesian, Elsevier https://doi org/10.1016/j.proenv.2015.07.068, 28, 578, 586

O'Leary DW, Friedman JD, Pohn HA (1976) Lineaments, linear, lineation-some proposed new standards for old terms. GeolSoc Am Bull 87(10):1463-1469. https://doi.org/10.1130/0016-7606(1976)87<1463:LLLSPN>2.0.CO;2

Owens PR, Rutledge EM (2005) Geomorphology. Encyclopedia of Soils in the Environment, Elsevier https://doi.org/10.1016/B0-12-348530-4/00002-3

Redshaw P, Boon D, Campbell G, Willis M, Mattai J, Free M, Jordan C, Kemp SJ, Morley A, Thomas M (2019) The 2017 regent landslide, Freetown peninsula, Sierr Leone Q J Eng Geol Hydrogeol https://doi.org/10.1144/qjedh2018-187, $52,4,435,444$

Royal Museum for Central Africa (2016) The Natural Disaster Database for Central Africa. http://www.africamuseum.be/collections/browsecollections/natura Isciences/earth/hazard, Accessed 30 Dec 20119

Sander P, Timothy B, Mathew M, Chesley M (2005) Groundwater Exploration Based on lineament Analysis and Reproducibility Tests. https://doi.org/1 0.1111/j.1745-6584.1997.t600157.x
Sankoh FP, Yan X (2013) Problems of solid waste Management in Developing Urban Cities: a case study of Freetown, Sierra Leone. Am J Environ Protect 2(5):113-120. https://doi.org/10.11648/j.ajep.20130205.11

Schluter T, Trauth M (2008) Geological atlas of Africa-with notes on stratigraphy, tectonics, economic geology, geohazards and geosites each country. Springer-Verlag, Berlin, Germany

Segoni S, Pappafico G, Luti T, Catani F (2019) Landslide susceptibility assessment in complex geological setting: sensitivity to geological information and insights on its parameterization. Landslides-Techn Note 17(10):2443-2453. https://doi.org/10.1007/s10346-019-01340-2

Sillah SK, Turay ES, Kargbo YJ, Minah AA, Bangura A, Bao K, Bangura EA, Kamara U, Bangura M, Sesay AM, Williams BK, Lahai YA, Conteh RM (2019) Geological assessment of Landslide site at Madina Hill locality, Mortomeh, Regent. https://doi.org/10.13140/RG.2.2.35232.53760

Skilodimou HD, Bathrellos G, Maroukian H, Gbakipapanastassiou K (2018) Physical and anthropogenic factors related to landslide activity in the northern Peloponnese, Greece Land-MDPI https://doi.org/10.3390/land7030085

Taylor ET, Kamara IS, Bockarie A (2014) Rainfall pattern in Freetown, Sierra Leone: from a retrospective viewpoint. Paper presented at the international conference ADAPT to CLIMATE, Nicosia Cyprus, 27-28 march 2014

Thomas MF (1983) Comtemporary denudation systems and the effects of climate change in the humid tropics-some problems from Sierra Leone. In: Briggs DJ, Waters RS (eds) Studies in quaternary geomorphology. Geo Books, Norwich, pp 195-214

Thomas MF (1994) Geomorphology in the tropics. John Wiley \& Sons Ltd, Chichester

Thomas MF (1998) Landscape sensitivity in the humid tropics: a geomorphological appraisal. In: Maloney BK (ed) Human activities and the tropical rainforest. Past, present and possible future. Springer-Science Business Media, B V, pp 17-47. https://doi.org/10.1007/978-94-017-1800-4_2

UNDP \& EPA (2017) Technical publication: analysis of the causal and trigger factors of the august 2017 landslide risk management in Freetown, Sierra Leone. United Nations Development Programme and Environmental Protection Agency, Freetown

Van Den Eeckhaut M, Moeyersons J, Nyssen J, Abraha A, Poesen J, Haile M, Deckers J (2009) Spatial patterns of old, deep-seated landslides: a case-study in the northern Ethiopia highlands. Geomorphology 105(3-4):239-252. https://doi.org/10.1016/j.geomorph.2008.09.027

Venkatakrishnan R, Culver SJ (1989) Tectonic fabric of Sierra Leone, West Africa: implications for Mesozoic continental breakup. J Geol Soc 146(6): 991-1002. https://doi.org/10.1144/gsjgs.146.6.0991

Vipin K, Vikram G, Sundriyal YP (2018) Spatial interrelationship of landslides, litho-tectonics, and climate regime, Satlug valley, Northwest Himalaya Wiley Online Library Geological J https://doi.org/10.1002/gj.3204, 54, 1, 537, 551

Xing A, Wang G, Li B, Jiang Y, Feng Z, Kamai T (2015) Long-runout mechanism and landsliding behaviour of large catastrophic landslide triggered by heavy rainfall in Guanling, Guizhou, China. Can Geotech J 52(7):1-11. https://doi. org/10.1139/cgj-2014-0122

Xu C, Tian Y, Zhou B, Ran H, Lyu G (2017) Landslide damage along Araniko highway and Pasang Lhamu highway and regional assessment of landslide hazard related to the Gorkha, Nepal earthquake of 25 April 2015. Geoenvironmental Disasters 4(1):14. https://doi.org/10.1186/s40677-017-0078-9

\section{Publisher's Note}

Springer Nature remains neutral with regard to jurisdictional claims in published maps and institutional affiliations. 